\title{
Article
}

\section{Determinants of Mobile Phone Penetration: Panel Threshold Evidence from Sub-Saharan Africa}

\author{
Asongu, Simplice, Nwachukwu, Jacinta Chikaodi and Aziz, Aqsa \\ Available at http://clok.uclan.ac.uk/25162/ \\ Asongu, Simplice, Nwachukwu, Jacinta Chikaodi ORCID: 0000-0003-2987-9242 \\ and Aziz, Aqsa (2018) Determinants of Mobile Phone Penetration: Panel \\ Threshold Evidence from Sub-Saharan Africa. Journal of Global Information \\ Technology Management, 21 (2). pp. 81-110. ISSN 1097-198X
}

It is advisable to refer to the publisher's version if you intend to cite from the work. http://dx.doi.org/10.1080/1097198X.2018.1462069

For more information about UCLan's research in this area go to http://www.uclan.ac.uk/researchgroups/ and search for <name of research Group>.

For information about Research generally at UCLan please go to http://www.uclan.ac.uk/research/

All outputs in CLoK are protected by Intellectual Property Rights law, including Copyright law. Copyright, IPR and Moral Rights for the works on this site are retained by the individual authors and/or other copyright owners. Terms and conditions for use of this material are defined in the policies page.

\section{CLoK}

Central Lancashire online Knowledge www.clok.uclan.ac.uk

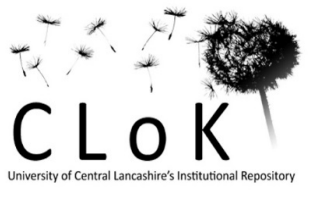




\title{
A G D I Working Paper
}

\author{
$\mathrm{WP} / 16 / 046$
}

Determinants of Mobile Phone Penetration: Panel Threshold Evidence from Sub-Saharan Africa

\author{
Simplice A. Asongu \\ African Governance and Development Institute \\ P.O. Box 8413, Yaoundé, Cameroon \\ E-mail: asongusimplice@yahoo.com \\ Tel: 0032473613172 \\ Jacinta C. Nwachukwu \\ School of Economics, Finance and Accounting, \\ Faculty of Business and Law, \\ Coventry University \\ Priory Street, Coventry, CV1 5FB, UK \\ Email: jacinta.nwachukwu@ coventry.ac.uk
}


Research Department

\title{
Determinants of Mobile Phone Penetration: Panel Threshold Evidence from Sub- Saharan Africa
}

\section{Simplice A. Asongu \& Jacinta C. Nwachukwu}

November 2016

\begin{abstract}
Despite the evolving literature on the development benefits of mobile phones, we still know very little about factors that influence their adoption. Using twenty five policy variables, we investigate determinants of mobile phone penetration in 49 Sub-Saharan African countries with data for the period 2000-2012. The empirical evidence is based on contemporary and non-contemporary OLS, Fixed effects, System GMM and Quantile regression techniques. The determinants are classified into six policy categories. They are: (i) macroeconomic, (ii) business/bank, (iii) market-related, (iv) knowledge economy, (v) external flows and (vi) human development. Results are presented in terms of threshold and non-threshold effects. The former has three main implications. First, there are increasing positive benefits in regulation quality, human development, foreign investment, education, urban population density and internet penetration. Second, there is evidence of decreasing positive effects from patent applications. Third, increasing negative impacts are established for foreign aid and return on equity. Non-threshold tendencies are discussed. Policy implications are also covered with emphasis on policy syndromes to enhance more targeted implications for worst performing nations.
\end{abstract}

JEL Classification: C23; L96; O11; O33; O55

Keywords: Panel data; Mobile phones; Development; Africa 


\section{Introduction}

Many industries are currently being disrupted by the mobile phone ${ }^{1}$ revolution which is not only changing interaction networks, but also providing services to previously untapped niches, including banking and healthcare. Mobile applications are increasingly being developed to improve, inter alia: payment solutions for Small and Medium Size Enterprises (SMEs); greater interaction among corporations; consultation of physicians and monitoring of personal health and enhancement of services for the underserved people. Some of such services include the provision of mobile banking facilities to those previously excluded from formal financial services and improvement of rural health workers' performances by means of mobile health applications (Asongu \& De Moor, 2015).

According to the narrative, there is an evolving stream of literature that has been motivated by the need for more scholarly research on the impact of mobile phones on development (Mpogole et al, 2008, p. 71). According to Kliner et al. (2013), mobile phones have been consistently improving health services delivered to rural communities. This is in line with the position of Kirui et al. (2013) on the benefits on mobile banking in fighting poverty in these communities: 'We conclude that mobile phone-based money transfer services in rural areas help to resolve a market failure that farmers face; access to financial services' (p. 141). This is essentially because the benefits of mobile technology are more apparent for the underprivileged such as the population in rural areas (Warren, 2007). The author believes that rural communities would benefit most from the technology because it stifles barriers in the areas of 'commodity purchase' and 'information acquisition'. According to Mishra and Bisht (2013), in many fast emerging economies and despite efforts furnished by mainstream financial institutions, 'Telecommunication infrastructure growth especially mobile phone penetration has created an opportunity for providing financial inclusion' (p.503). In India,

\footnotetext{
${ }^{1}$ Mobile, mobile phones, mobile telephony and cell phones are used interchangeably throughout this study.
} 
Singh (2012, p. 466) has adopted a more direct stance in acknowledging the contribution of 'mobile banking' in financial inclusion. Economic opportunities have also been enhanced with the transformation of mobile phones into pocket banks, which have provided financial access to the low-income or previously unbanked strata of the population in developing countries (Demombynes \& Thegeya, 2012; Asongu, 2013).

As far as we have reviewed, the current literature on mobile phones can be classified into three main streams; reducing the rural/urban gap, female empowerment and improving health services

The first stream articulates the following. (i) Challenges of production, employment and distribution of food faced by rural communities. The information gap bridged by mobile telephony generates substantial positive externalities in terms of job creation and incremental income generation. For instance, studies in Ghana have shown that increased access to 'market information' leads to an income surge of about 10 percent (E-agriculture, 2012, p. 69). (ii) SMEs and cooperatives are supported by 'mobile banking'-driven agricultural finance. This is the case in Costa Rica with financially-sustainable groups (Perez et al., 2011, p. 316) and Community Credit Enterprises (CCE) which foster sustainable business models. According to the World Bank, mobile phones are playing a crucial role in the development of agriculture and rural areas (Qiang et al., 2011, pp. 14-26). This is consistent with the position of Chan and Jia (2011) on the benefits of mobiles in facilitating rural loans, 'mobile banking is an ideal choice for meeting the rural financial needs' (p. 3) as a result of increasing 'rates for bank transfers through mobile cell phones at commercial banks' (Table 2, p. 5). (iii) As reported by Muto and Yamano (2009) and Aker and Fafchamps (2010), demand- and supplyside constraints in agricultural productivity and rural livelihoods are increasingly being mitigated by the mobile technology, which is easing mechanisms for 'high-growth/return markets' to farmers. The crucial issue tackled here is how the mobile is used to improve rural 
livelihoods through better demand- and supply-matching and/or reduce wastes through matching networks.

The second strand on female empowerment provides evidence of the increasing participation of women in communities due to more financial inclusion. Documented mechanisms for greater inclusion entail, inter alia: household management and consolidation of small businesses (Asongu \& Nwachukwu, 2016a). According to Jonathan and Camilo (2008), Asongu (2015a) and Ondiege (2010, 2013), mobile phones reduce the gender-finance gap and enable timely household responses to poverty-related shocks. Some examples, include: reduced cost of travelling, income saving, education, multi-tasking and management of household budgets (Al Surikhi, 2012; Asongu, 2015bc). Country-specific models provided by Ondiege (2010, p. 11) and Mishra \& Bisht (2013, p. 505) are supported by appropriate government policies. This is consistent with the conclusions of Ojo et al. (2012) who have investigated how mobile phones have affected the livelihoods of women in Ghana and Maurer (2008) on the caution that the role of policy-making bodies is critical in maintaining the gender inclusive benefits of mobile services.

In the third strand, we find literature on the employment of mobile phones for medical devices and improvement of healthcare. According to West (2013), healthcare quality and affordability in the world have been substantially improved. Challenges based on geographic and income disparities are increasingly been tackled through mobile applications that ameliorate healthcare delivery. Hence, by connecting patients to providers of healthcare, mobile phones improve on the delivery of healthcare by means of, among other things: laboratory tests, access to reference material and medical records. Some examples include designing of mobile devices for clinical appointments (Da Costa et al., 2010), observation and treatment of tuberculosis patients (Hoffman et al., 2010) and self-monitoring and tailored feedback (Bauer et al., 2010). 
Despite the evolving literature on the development benefits of mobile phones, we know very little about factors that influence the adoption of them. Madden and Coble-Neal (2004) examined the economic determinants of global mobile telephony adoption and concluded that price ceilings levelled in networks with fixed-line delay mobile network growth. Then too, Madden et al. (2004) showed that 'technically advanced mobile cellular networks' are driving mobile adoption. Abu and Tsuji (2010) found telecom infrastructure as a significant determinant. Tseng and Lo (2011) assessed antecedents of intentions of consumers' move to upgrade their mobile and found that they are unwilling to adopt a more recent generation model when they are satisfied with their usage of the current network. Penard et al. (2012) assessed if cell phone adoption processes in Africa are different from those of other regions to establish that the principal obstacles to mobile phone use are ageand economically-related. Factors determining mobile phone penetration in Africa and Asia were examined by Doshi and Narwold (2014) using panel data for the period 2001-2012. They established the following as significant determinants: population growth, rural rate, population density, fixed lines penetration and Gross Domestic Product (GDP) per capita. This last study is closest to the current line of inquiry in terms of sample periodicity and data structure.

The above literature on determinants leaves room for improvement in at least six main areas: updated evidence, more robust panel methodology, conditional determinants, contemporary specifications, use of more determinants and derivation of policy syndromes. First, the use of a data structure for the period 2000-2012 provides updated evidence to complement studies like Madden and Coble-Neal (2004) and Madden et al. (2004) that are based for the most part on data collected before the year 2000. Second, on the methodology, contrary to Doshi and Narwold (2014) that is essentially based on panel Fixed-effects (FE), this study employs a battery of panel estimation techniques that are more robust to 
endogeneity and the behaviour of mobile phone data. Accordingly, we employ baseline Ordinary Least Squares (OLS) regressions, FE estimations and a dynamic system Generalised Method of Moments (GMM) with forward orthogonal deviations. This last technique controls for cross-sectional dependence, avoids potential biases in traditional GMM techniques and accounts for the persistent feature in mobile phone penetration. Third, contrary to the underlying literature, average effects may not lead to more targeted policy implications. Hence, we also assess the determinants of mobile phone penetration throughout its conditional distribution. This enables us to distinguish between best and worst countries in terms of mobile penetration, such that policy lessons for least- performers are clearly articulated from the success of their better-performing counterparts. The intuition for this specification is that blanket policies may not be effective unless they are contingent on initial mobile phone penetration levels and tailored differently across best- and worst-performing countries in mobile adoption. Fourth, in order to increase subtlety in the policy implications, the specifications are modelled in terms of contemporary and non-contemporary determinants. This facilitates the timing of mobile phone adoption policies. Fifth, as far as we know, determinants used in the underlying literature have not been many. For instance, Doshi and Narwold (2014) who have employed a comparatively large number of variables have used eight determinants. In this study, we use 25 determinants classified into six categories: (i) macroeconomic policy, (ii) bank-related, (iii) market-oriented, (iv) knowledge economy, (v) external flows and (vi) human development variables. Each category has at least three variables and specifications are tailored to mitigate potential issues of overparameterization and multicollinearity. Sixth, in order to enhance more focused policy implications, we decompose the sample into fundamental characteristics and provide conditions on which the assessed determinants are most relevant. 
The above gaps are filled by positioning the line of inquiry on Africa for a threefold reason. First, Africa is experiencing a relative asymmetric development in terms of mobile phone and internet penetrations. Consistent with Penard et al. (2012), while within developed nations both penetrations have risen in tandem to a point of market saturation, the uneven penetration has been characterized by cell phones substantially outpacing internet deepening by 41 percent against 9.6 percent (as of 2010). Second, according to Micheal (2013), emerging markets in Africa constitute the next big business avenue because mobile phone adoption rates have stabilized in high-end markets like Asia, Europe and North America. Third, a recent World Bank report on mobile phones has shown that African countries are in the drivers' seat when it comes to their usage for mobile banking activities (MosheniCheraghlou, 2013).

Theoretical underpinnings for the adoption of a new technology have been substantially documented by Yousafzai et al. (2010, p. 1172). Some of the most popular include, the: theory of reasoned action (TRA), theory of planned behavior (TPB) and technology acceptance model (TAM). A common denominator among the underlying theories is that the mobile phone adoption process is complex and multifaceted, entailing, inter alia: (a) an approach from information managers and system developers that is centered on the customer's formation of belief and not on the influence of attitudes and (b) crucial features which include composite considerations like customers' personal, social, psychological, utilitarian and behavioral aspects. First, consistent with Yousafzai et al., the TRA, developed by Fishbein and Ajzen (1975), Ajzen and Fishbein (1980) and Bagozzi (1982) is based on the assumption that customers are rational when it comes to considering the implications of their actions. Second, the TPB pioneered by Ajzen (1991) has extended the TRA by articulating the absence of differences between customers who have a conscious control over their actions from those that do not. Third, the TAM developed by Davis (1989) assumes that the adoption 
process of a given technology by a customer can be explained by the customer's voluntary intention to accept and use the technology.

The rest of the study is organized as follows. Section 2 discusses the data and methodology. The empirical analysis, discussion of results and implications are covered in Section 3. Section 4 concludes.

\section{Data and Methodology}

\subsection{Data}

We assess a panel of 49 Sub-Saharan African (SSA) countries with data from African Development Indicators (ADI) of the World Bank and Nguena et al. (2015) for the period 2000-2012.The dependent variable is the mobile phone penetration rate (per 100 people). As we noted earlier, six main categories of independent variables are employed. They are (i) four macroeconomic and trade policy variables (trade openness, money supply, inflation and Gross Fixed Capital Formation (GFCF)); (ii) six business/bank-related indicators for investment incentives (Net Interest Margin (NIM), Loan Deposit Spread (LDS), Interest Rate Spread (IRS), Bank density, Return on Assets (ROA) and Return on Equity (ROE)); (iii) three market-oriented determinants for market size, market growth and market structure (GDP growth, Population growth and Urban population); (iv) five indicators for the World Bank's four knowledge economy index (KEI) components (secondary school enrolment for education, regulation quality denoting institutional regime, patent applications for innovation, internet penetration representing information and communication technology (ICT) and private domestic credit for economic incentives); (v) three external flows (Foreign Direct Investment, Foreign aid and Remittances) and (vi) three human development indicators (the human development index (HDI), household capital expenditure and domestic savings). A similar set of variables has been used by Asongu (2015c) which exclusively focuses on cross- 
sectional data for the year 2011 because mobile banking data was only available for that year. This inquiry steers clear of Asongu (2015c) at three levels. First, findings of the underlying study can be simply interpreted as correlations, not causalities. This is not the case with the present study. Second, the underlying study focuses on mobile banking and mobile phone penetration for the year 2011. Third, we employ panel estimation strategies that are not consistent with the cross-sectional oriented line of inquiry.

The first-three categories are consistent with the United Nations Conference on Trade and Development (UNCTAD, 2002) classification of economic determinants, which have been employed in recent literature on macroeconomic determinants (see Akpan et al., 2014; Asongu \& Nwachukwu, 2015; Asongu \& Kodila-Tedika, 2015). The choice of knowledge economy (KE) variables is motivated by Wang et al. (2009) who have concluded that knowledge is an important determinant of mobile phone adoption. While the inclusion of external flows is motivated by the significant positive effect witnessed during the sample periodicity (See Figure 1 of Ssozi \& Asongu, 2015), the human development indicators are consistent with the underlying mobile phone literature discussed in the preceding section.

It is difficult to provide expected signs for the 25 variables under consideration. This is essentially because of the absence of prior literature that has documented the relationship between mobile penetration and most of the underlying variables. Hence, we shall engage our intuition for the expected signs concurrently with the discussion of results. The selected categories of determinants and definition of variables are presented in Table 1 and Table 2 respectively. 
Table 1: Mobile phone/banking determinants

\begin{tabular}{|c|c|}
\hline Determining Variables & Examples \\
\hline Policy variables (4) & $\begin{array}{l}\text { Trade policy, macroeconomic policy (Trade, M3, } \\
\text { Inflation, GFCF) }\end{array}$ \\
\hline Business/Bank variables (6) & $\begin{array}{l}\text { Investment incentives (NIM, LSD, IRS, Bank density, } \\
\text { ROA, ROE) }\end{array}$ \\
\hline Market-related economic determinants (3) & $\begin{array}{l}\text { Market size, market growth, market structure (GDPg, } \\
\text { Popg, Ubanpop) }\end{array}$ \\
\hline Knowledge Economy (5) & $\begin{array}{l}\text { Education (SSE), Institutional Regime (RQ), Innovation } \\
\text { (Patents), ICT (Internet), Economic incentives (Private } \\
\text { credit). }\end{array}$ \\
\hline External Flows (3) & FDI, NODA, Remi \\
\hline Human development (3) & HDI, HHCExp, Domestic savings \\
\hline
\end{tabular}

Source: Authors. M3: Money Supply. GFCF: Gross Fixed Capital Formation. NIM: Net Interest Margin. LSD: Loan Deposit Spread. IRS: Interest Rate Spread. ROA: Return on Assets. ROE: Return on Equity. GDPg: GDP growth. Popg: Population growth. SSE: Secondary School Enrolment. RQ: Regulation Quality. Ubanpop: Urban population. FDI: Foreign Direct Investment. NODA: Net Official Development Assistance. Remi: Remittances. HDI: Human Development Index. HHCExp: Household Consumption Expenditure.

Adopted fundamental characteristics for the policy environment are classified in terms of income levels (low-income, middle-income, lower-middle-income and upper-middle-income), legal origins (English common law and French civil law), religious dominations (Christianity and Islam), openness to sea (landlocked and unlandlocked), oil exports (Oil- and Nonoilexporting) and conflicts (conflicts and Nonconflicts). For brevity, we do not discuss the criteria for the determination of these characteristics, but they can be provided upon request. The interested reader can find the justifications in Asongu (2015cd). 
Table 2: Variable definitions

\begin{tabular}{|c|c|c|c|c|}
\hline Categories & Variables & Signs & Definitions & Source \\
\hline Mobile phone/ & Mobile Phone & Mobile & Mobile phone subscriptions (per 100 people) & WDI \\
\hline \multirow{6}{*}{ Policy variables } & Trade & Trade & Imports + Exports of Good \& Services (\% of GDP) & WDI \\
\hline & Financial Depth & M3 & Money Supply (\% of GDP) & WDI \\
\hline & Inflation & Infl & Consumer prices (annual \%) & WDI \\
\hline & Domestic Invt. & GFCF & Gross Fixed Capital Formation (\% of GDP) & WDI \\
\hline & Interest Margin & NIM & Net Interest Margin (\%) & WDI \\
\hline & Loan Spread & LDS & Loan-Deposit Spread (\%) & WDI \\
\hline Business \& & Interest Spread & IRS & Interest Rate Spread (Lending rate minus Deposit rate, \%) & WDI \\
\hline \multirow[t]{3}{*}{ Bank variables } & Bank Density & Bbrchs & Commercial bank branches (per 100000 adults) & WDI \\
\hline & Bank Return 1 & ROA & Return on Assets (annual \%) & WDI \\
\hline & Bank Return 2 & ROE & Return on Equity (annual \%) & WDI \\
\hline \multirow{3}{*}{$\begin{array}{l}\text { Market-related } \\
\text { economic } \\
\text { variables }\end{array}$} & Eco. Growth & GDPg & Gross Domestic Product growth rate (annual \%) & WDI \\
\hline & Pop. Growth & Popg & Population growth rate (annual \%) & WDI \\
\hline & Urban Pop. & Ubanpop & Urban Population ( $\%$ of Total) & WDI \\
\hline \multirow{4}{*}{ External flows } & Foreign Invt. & FDI & Foreign Direct Investment net inflows (\% of GDP) & WDI \\
\hline & Remittances & Remi & Remittance inflows (\% of GDP) & WDI \\
\hline & Foreign Aid & NODA & Net Official Development Assistance (\% of GNI) & WDI \\
\hline & Human dev. & HDI & Human Development Index & WDI \\
\hline Household & HC Expenditure & $\mathrm{HCE}$ & Household Final Consumption Expenditure (\% of GDP) & WDI \\
\hline \multirow[t]{2}{*}{ Development } & Domestic Savings & DSav & Gross Domestic Savings (\% of GDP) & WDI \\
\hline & Education & SSE & Secondary School Enrolment (\% of Gross) & WDI \\
\hline Knowledge & Institutional Regime & RQ & Regulation Quality (Estimate) & WDI \\
\hline \multirow[t]{3}{*}{ Economy } & ICT & Internet & Internet penetration (per 100 persons) & WDI \\
\hline & Eco. Incentives & Credit & $\begin{array}{l}\text { Private credit by deposit banks and other financial institutions } \\
\text { (\% of GDP) }\end{array}$ & WDI \\
\hline & Innovation & Patents & Total patent applications & WDI \\
\hline
\end{tabular}

Eco: Economic. Pop: population. Ivt: Investment. HC: Household Consumption. WDI: World Development Indicators of the World Bank. GNI: Gross National Income.

Table 3 below provides the summary statistics. Two points are noteworthy. First, the variables in both structures are comparable (based on mean values). Second, the variables exhibit a substantial degree of variation so that we are confident that interesting estimated linkages will emerge. 
Panel (2000-2012)

Mobile Phone

Trade

Financial depth (M3)

Inflation

Domestic Investment

Net Interest Margin(NIM)

Loan-Deposit Spread (LDS)

Interest Rate Spread (IRS)

Bank Density

Return on Assets (ROA)

Return on Equity (ROE)

GDP growth rate (GDPg)

Population growth (Popg)

Urban Population (Ubanpop)

\begin{tabular}{|c|c|c|c|c|}
\hline Mean & Standard Deviation & Minimum & Maximum & Observations \\
\hline 23.37 & 28.00 & 0.00 & 147.2 & 572 \\
\hline 78.17 & 36.13 & 20.96 & 209.8 & 597 \\
\hline 34.39 & 21.76 & 8.12 & 171.6 & 198 \\
\hline 56.57 & 1017 & -9.61 & 24411 & 577 \\
\hline 20.31 & 9.606 & 1.096 & 78.56 & 559 \\
\hline 6.946 & 3.756 & -4.610 & 39.24 & 473 \\
\hline 12.13 & 8.778 & 0.530 & 69.94 & 359 \\
\hline 13.02 & 14.01 & 0.525 & 175.7 & 389 \\
\hline 5.236 & 7.872 & 0.129 & 48.28 & 371 \\
\hline 2.177 & 2.226 & -14.91 & 13.47 & 477 \\
\hline 20.75 & 32.33 & -389.3 & 178.6 & 477 \\
\hline 4.714 & 6.322 & -47.55 & 63.38 & 608 \\
\hline 2.361 & 0.948 & -1.081 & 6.576 & 588 \\
\hline 36.27 & 16.92 & -1.175 & 86.45 & 637 \\
\hline 5.33 & 8.73 & -6.043 & 91.00 & 603 \\
\hline 3.977 & 8.031 & 0.000 & 64.10 & 434 \\
\hline 11.68 & 14.19 & -0.253 & 181.1 & 606 \\
\hline 0.466 & 0.107 & 0.262 & 0.769 & 411 \\
\hline 74.02 & 20.16 & 7.12 & 178.1 & 540 \\
\hline 11.29 & 21.87 & -87.53 & 89.62 & 557 \\
\hline 38.52 & 24.31 & 6.077 & 123.8 & 375 \\
\hline-0.715 & 0.644 & -2.665 & 0.983 & 578 \\
\hline 4.152 & 6.450 & 0.005 & 43.60 & 566 \\
\hline 18.55 & 22.47 & 0.550 & 149.7 & 507 \\
\hline 129.9 & 927.7 & 0.000 & 8317 & 637 \\
\hline
\end{tabular}

Foreign Direct Investment

Remittances

Foreign Aid

Human Development Index

Household Expenditure

Domestic Savings

Secondary School Enrolment

Regulation Quality

Internet Penetration

Private Domestic Credit

Patents

Given that we are using 25 explanatory variables, it is normal to expect potential issues of muliticollinearity and overparameterization. In the presence of these concerns, variables with a high degree of substitution enter into conflict and only some emerge with the expected signs. Given the policy orientation of the study, policy variables take precedence over the aforementioned misspecification biases. Moreover, we can also achieve the policy purpose while at the same time mitigating the effect of these errors by simply avoiding variables with a high degree of substitution in the same equation. Table 4 presents the corresponding correlation matrix. Correlations with a high degree of substitution are 
highlighted in bold. Specifications in the empirical sections are tailored to avoid combination of highly correlated variables in the same model ${ }^{2}$.

\footnotetext{
${ }^{2}$ For example the following sets of variables do not enter into the same specifications: IRS \& LDS, DSav \& HCE, SSE \& Internet, SSE \& Credit, SSE \& HDI, Patent \& Credit, SSE \& Bbrchs, IRS \& Inflation, SSE \& Popg, Internet \& Bbrchs, HDI \& Bbrchs and HDI \& Internet. 'Interest Rate Spread', 'Net Interest Margin' and 'Lending Deposit Rate' cannot all enter into the same specification because of concerns about mulitcollinearity. Only two of the variables can be employed in a given specification. In Table 5, 'Interest Rate Spread' is not used because 'Net Interest Margin' and 'Lending Deposit Rate' are used. In Table 6, 'Interest Rate Spread' is not used because 'Net Interest Margin' and 'Lending Deposit Rate' are used. In Table 7, Interest Rate Spread' is used either with 'Net Interest Margin' or 'Lending Deposit Rate'. In the light of these clarifications, the need to avoid concerns about multicollinearity justifies the multitudes of specifications in the empirical results section.
} 
Table 4: Correlation matrix

\begin{tabular}{|c|c|c|c|c|c|c|c|c|c|c|c|c|c|c|c|c|c|c|c|c|c|c|c|c|c|}
\hline \multirow[b]{2}{*}{ Trade } & \multicolumn{2}{|c|}{ Policy Variables } & \multirow[b]{2}{*}{ GFCF } & \multirow{2}{*}{ NIM } & \multicolumn{4}{|c|}{ Business/Bank Variables } & \multirow{2}{*}{ ROE } & \multicolumn{3}{|c|}{ Market-related } & \multirow{2}{*}{ FDI ${ }^{\mathbf{E}}$} & \multicolumn{2}{|c|}{ ternal Flows } & \multicolumn{3}{|c|}{ Household Development } & \multirow{2}{*}{ SSE } & \multicolumn{3}{|c|}{ Knowledge Economy } & \multirow[b]{2}{*}{ Patent } & \multirow[b]{2}{*}{ Mobile } & \multirow[b]{3}{*}{ Trod } \\
\hline & M3 & Infl. & & & LDS & IRS & Bbrchs & ROA & & GDPg & Popg & UPop & & Aid & Remi & & $\mathrm{HCE}$ & DSav & & $\mathrm{RQ}$ & Internet & Credit & & & \\
\hline \multirow{25}{*}{1.000} & 0.577 & 0.006 & 0.390 & -0.10 & 0.106 & 0.042 & 0.266 & 0.028 & 0.027 & 0.097 & -0.30 & 0.231 & 0.338 & -0.062 & 0.447 & 0.370 & -0.17 & 0.114 & 0.32 & 0.023 & 0.182 & 0.013 & -0.074 & 0.243 & \\
\hline & 1.000 & 0.225 & 0.095 & -0.04 & -0.25 & -0.02 & 0.632 & 0.152 & 0.188 & -0.18 & -0.64 & 0.458 & 0.177 & -0.464 & -0.02 & 0.774 & -0.32 & 0.338 & 0.75 & 0.166 & 0.531 & 0.337 & 0.109 & 0.411 & M3 \\
\hline & & 1.000 & -0.08 & 0.25 & 0.539 & 0.70 & -0.009 & -0.05 & -0.01 & -0.07 & -0.13 & -0.00 & -0.02 & -0.007 & -0.07 & -0.02 & 0.05 & -0.03 & -0.04 & -0.13 & 0.043 & -0.06 & -0.007 & -0.028 & Infl \\
\hline & & & 1.000 & -0.18 & -0.07 & -0.16 & 0.275 & -0.06 & 0.05 & 0.286 & 0.075 & -0.04 & 0.385 & 0.006 & 0.212 & 0.248 & -0.30 & 0.278 & 0.11 & 0.264 & 0.119 & 0.029 & -0.032 & 0.216 & GFCF \\
\hline & & & & 1.00 & 0.142 & 0.118 & -0.279 & 0.485 & 0.232 & 0.031 & 0.160 & -0.24 & -0.005 & 0.251 & 0.009 & -0.37 & 0.339 & -0.27 & -0.20 & -0.09 & -0.223 & -0.24 & -0.128 & -0.273 & NIM \\
\hline & & & & & 1.00 & 0.999 & -0.211 & -0.01 & -0.04 & 0.033 & 0.309 & 0.074 & 0.160 & 0.104 & -0.05 & -0.34 & -0.08 & 0.072 & -0.30 & -0.32 & -0.228 & -0.33 & -0.165 & -0.258 & LDS \\
\hline & & & & & & 1.000 & -0.141 & 0.065 & 0.014 & -0.10 & 0.017 & 0.032 & 0.048 & 0.034 & -0.05 & -0.27 & $\begin{array}{l}-0.009 \\
-0.009\end{array}$ & -0.005 & $\begin{array}{l}-0.30 \\
-0.30\end{array}$ & -0.37 & -0.122 & -0.21 & -0.11 & -0.207 & IRS \\
\hline & & & & & & & 1.000 & -0.03 & 0.012 & -0.03 & -0.50 & 0.116 & 0.006 & -0.152 & -0.03 & 0.705 & -0.169 & 0.134 & 0.80 & 0.327 & 0.836 & 0.390 & 0.048 & 0.579 & Bbrchs \\
\hline & & & & & & & & 1.000 & 0.489 & 0.061 & 0.044 & -0.11 & -0.12 & 0.018 & 0.001 & 0.021 & 0.081 & -0.09 & 0.05 & 0.055 & -0.092 & -0.07 & -0.07 & -0.094 & ROA \\
\hline & & & & & & & & & 1.000 & 0.012 & -0.02 & -0.04 & -0.07 & 0.009 & -0.001 & -0.003 & -0.005 & -0.018 & 0.034 & 0.050 & -0.081 & -0.05 & -0.016 & -0.051 & ROE \\
\hline & & & & & & & & & & 1.000 & 0.266 & $\begin{array}{l}-0.02 \\
-0.02\end{array}$ & 0.122 & 0.064 & -0.002 & -0.052 & 0.124 & 0.163 & -0.11 & 0.052 & -0.044 & -0.06 & -0.024 & 0.044 & GDPg \\
\hline & & & & & & & & & & & 1.000 & -0.21 & 0.082 & 0.359 & -0.17 & -0.53 & 0.051 & -0.02 & -0.67 & -0.17 & -0.43 & -0.38 & -0.16 & -0.334 & Popg \\
\hline & & & & & & & & & & & & 1.000 & 0.134 & -0.16 & -0.16 & 0.414 & -0.33 & 0.369 & 0.344 & 0.096 & 0.175 & 0.132 & 0.185 & 0.375 & UPop \\
\hline & & & & & & & & & & & & & 1.000 & 0.283 & 0.120 & 0.004 & -0.00 & 0.024 & 0.026 & -0.11 & 0.038 & -0.09 & -0.055 & 0.070 & FDI \\
\hline & & & & & & & & & & & & & & 1.000 & $\begin{array}{r}-0.009 \\
\end{array}$ & $\begin{array}{l}-0.34 \\
-0.0\end{array}$ & 0.498 & -0.47 & -0.41 & -0.21 & -0.173 & -0.17 & -0.11 & -0.220 & Aid \\
\hline & & & & & & & & & & & & & & & 1.000 & -0.04 & 0.439 & -0.57 & -0.04 & -0.05 & -0.02 & -0.07 & -0.07 & -0.050 & Remi \\
\hline & & & & & & & & & & & & & & & & 1.000 & 0.426 & 0.400 & 0.899 & 0.503 & 0.663 & 0.514 & 0.204 & 0.690 & HDI \\
\hline & & & & & & & & & & & & & & & & & 1.000 & -0.94 & -0.28 & -0.17 & -0.106 & -0.08 & -0.09 & -0.223 & HCE \\
\hline & & & & & & & & & & & & & & & & & & 1.000 & 0.214 & 0.135 & 0.093 & 0.015 & 0.048 & 0.224 & DSav \\
\hline & & & & & & & & & & & & & & & & & & & 1.000 & 0.470 & 0.703 & 0.622 & 0.354 & 0.699 & SSE \\
\hline & & & & & & & & & & & & & & & & & & & & 1.000 & 0.261 & 0.580 & 0.272 & 0.346 & $\mathrm{RQ}$ \\
\hline & & & & & & & & & & & & & & & & & & & & & 1.000 & 0.439 & 0.126 & 0.696 & Internet \\
\hline & & & & & & & & & & & & & & & & & & & & & & 1.000 & 0.799 & 0.428 & Credit \\
\hline & & & & & & & & & & & & & & & & & & & & & & & 1.000 & 0.246 & Patent \\
\hline & & & & & & & & & & & & & & & & & & & & & & & & 1.000 & Mobile \\
\hline
\end{tabular}

M3: Money Supply. Infl: Inflation. GFCF: Gross Fixed Capital Formation. NIM: Net Interest Margin. LDS: Lending Deposit Spread. IRS: Interest Rate Spread. Bbrchs: Bank Density. ROA: Return on Assets. ROE: Return on Equity. GDPg: GDP growth. Popg: Population growth. UPop: Urban population. FDI: Foreign Direct Investment. Aid: Net Official Development Assistance. Remi: Remittance. HDI: Human Development Index. HCE: Household consumption expenditure. DSav: Domestic savings. SSE: Secondary School Enrolment. RQ: Regulation Quality. Internet: internet penetration. Credit: Private Domestic Credit. Patent: Total patent applications. Mobile: Mobile phone penetration. Potential issues of multicollinearity highlighted in bold. 


\subsection{Estimation techniques}

Four estimation techniques are adopted in order to control for a multitude of factors, notably:

(i) baseline contemporary and non-contemporary Ordinary Least Squares; (ii) contemporary and non-contemporary Fixed effects (FE) regressions to control for the unobserved heterogeneity; (iii) the Generalised Method of Moments (GMM) to account for persistence in mobile phone penetration and (iv) Quantile Regressions (QR) to control for initial levels of mobile phone penetration. The GMM approach is motivated by persistence in mobile phone penetration as well as the need to also account for simultaneity and time-invariant omitted variables. The use of non-contemporary regressions in order to control for potential endogeneity bias is in accordance with recent literature (Mlachila et al., 2014, p.21; Asongu \& Nwachukwu, 2016b).

\subsubsection{Determinants based on Panel OLS and Fixed-Effects}

Contemporary and non-contemporary Ordinary Least Squares (OLS) with Heteroscedasticity and Autocorrelation Consistent (HAC) standard errors are complemented with Fixed-Effects regressions.

\section{Baseline OLS panel regressions}

-Baseline Panel contemporary determinants (Left Hand Side (LHS) of Table 5)

$$
\text { Mobile }_{i, t}=\alpha+\sum_{j=1}^{25} \sum_{h=1}^{25} \delta_{j} W_{h, i, t}+\xi_{t}+\varepsilon_{i, t}
$$

Where: Mobile $_{i, t}$ is the Mobile phone penetration rate for country $i$ at period $t ; \alpha$ is a constant, $W$ is the vector of determinants, $\xi_{t}$ is the time specific effect and $\varepsilon_{i, t}$ the error term . -Baseline Panel non-contemporary determinants (Right Hand Side (RHS) of Table 5)

$$
\text { Mobile }_{i, t}=\alpha+\sum_{j=1}^{25} \sum_{h=1}^{25} \delta_{j} W_{h, i, t-1}+\xi_{t}+\varepsilon_{i, t}
$$


Eqs (1) and (2) are based on HAC standard errors, with control of the unobserved heterogeneity in time-effects.

\section{Panel fixed-effects (FE)}

-Panel FE contemporary determinants (Left Hand Side (LHS) of Table 6)

$$
\text { Mobile }_{i, t}=\alpha+\sum_{j=1}^{25} \sum_{h=1}^{25} \delta_{j} W_{h, i, t}+\eta_{i}+\xi_{t}+\varepsilon_{i, t}
$$

Where: $\eta_{i}$ is the country-specific effect

-Panel FE non-contemporary determinants (Right Hand Side (RHS) of Table 6)

$$
\text { Mobile }_{i, t}=\alpha+\sum_{j=1}^{25} \sum_{h=1}^{25} \delta_{j} W_{h, i, t-1}+\eta_{i}+\xi_{t}+\varepsilon_{i, t}
$$

Eqs (3) and (4) are based on HAC standard errors with control for both country-specific and time effects.

\subsubsection{Determinants based on a dynamic panel (Table 7)}

The choice of a GMM technique has at least five justifications. Whereas the first-two are requirements for the employment of the estimation approach, the last-three are related advantages. First, the technique enables the control for persistence in mobile phone penetration, given that the criterion for continuation of mobile phone penetration is met. Accordingly, the correlation between mobile phone penetration and its first lag is 0.987 which is above the 0.800 criterion used to ascertain persistence in dependent variables. Second, the $\mathrm{N}$ (or 49)>T(or 13) criterion for the employment of the GMM technique is also met because the number of time series in each cross section is lower than the number of cross sections. Third, the empirical strategy accounts for endogeneity in all regressors by controlling for time invariant omitted variables and using instrumental values of regressors. Fourth, the system GMM estimator accounts for small biases in the difference GMM estimator. Fifth, crosscountry variations are considered in the specifications. 
In essence, the system GMM estimator (Blundell \& Bond, 1998; Arellano \& Bond, 1995) has been documented to have better properties than the difference estimator of Arellano and Bond (1991) (see Bond et al., 2001, pp. 3-4).

Eq. (5) and Eq (6) represent system Generalized Method of Moments (GMM) specifications in level and first difference respectively. The adopted GMM strategy employs two-step forward orthogonal deviations instead of first differences. This extension by Roodman (2009ab) of Arellano and Bover (1995) has been documented to provide more efficient estimates in the presence of cross-sectional dependence (see Love \& Zicchino, 2006; Baltagi, 2008).

$$
\text { Mobile }_{i, t}=\alpha+\text { SMobile }_{i, t-\tau}+\sum_{j=1}^{25} \sum_{h=1}^{25} \delta_{j} W_{h, i, t-\tau}+\eta_{i}+\xi_{t}+\varepsilon_{i, t}
$$

Mobile $_{i, t}-$ Mobile $_{i, t-\tau}=\alpha+\delta\left(\right.$ Mobile $_{i, t-\tau}-$ Mobile $\left._{i, t-2 \tau}\right)+\sum_{j=1}^{25} \sum_{h=1}^{25} \delta_{j}\left(W_{h, i, t-\tau}-W_{h, i, t-2 \tau}\right)+\left(\xi_{t}-\xi_{t-\tau}\right)+\varepsilon_{i, t-\tau}$ (6)

Where: $\tau$ represents the coefficient of autoregression.

We now discuss exclusion and identification restrictions. Consistent with recent literature, all independent variables are considered as suspected endogenous or predetermined variables while only years are considered as strictly exogenous (Dewan \& Ramaprasad, 2014; Asongu \& Nwachukwu, 2016c). In essence, it is not likely for years to become endogenous in first-difference (see Roodman, 2009b). Hence, the procedure for treating ivstyle (years) is 'iv(years, eq(diff))' while the gmmstyle is adopted for predetermined or suspected endogenous variables.

In the light of the above, years or the strictly exogenous instruments affect mobile phone penetration exclusively via endogenous explaining or predetermined variables. Moreover, the statistical validity of the exclusion restriction is assessed with the Difference in Hansen Test (DHT) for instrument exogeneity. In essence, the null hypothesis of this test 
should not be rejected in order for the instruments to elucidate mobile phone penetration exclusively through the predetermined indicators. Accordingly, while in the standard instrumental variable (IV) approach, a rejection of the null hypothesis of the Sargan Overidentifying Restrictions (OIR) test is an indication that the instruments elicit the outcome variable beyond the predetermined variables (see Beck et al., 2003; Asongu \& Nwachukwu, 2016d), in the GMM approach with forward orthogonal deviations, the information criterion used to assess if years exhibit strict exogeneity is the DHT. Therefore, in the GMM results that would be reported, the exclusion restriction is confirmed if the alternative hypothesis of the DHT corresponding to IV (year, eq(diff)) is rejected.

\subsubsection{Conditional determinants based on Quantile regression}

We also employ the Quantile regression (QR) technique to investigate if the determinants of mobile phone vary throughout the conditional distributions of mobile phone penetration. Hence, the intuition for this approach is that blanket policies used to boost mobile penetration may not be effective unless they are contingent on initial levels of mobile phone penetration and tailored differently across best-performing and worst -performing countries. In this light, lessons drawn from the former nations could be applied to the latter countries, in terms of significant determinants of the dependent variable. The adopted QR which is consistent with the underpinnings of Keonker and Hallock (2001) is increasingly being employed in development literature (Billger \& Goel, 2009; Okada \& Samreth, 2012; Asongu, 2014ab).

The $\theta^{\text {th }}$ quantile estimator of the dependent variable is derived after estimating Eq. (7) below.

$$
\min _{\beta \in R^{k}}\left[\sum_{i \in\left\{i: y_{i} \geq x_{i}^{\prime} \beta\right.} \theta\left|y_{i}-x_{i}^{\prime} \beta\right|+\sum_{i \in\left\{i: y i \geq x_{i}^{\prime} \beta\right.}(1-\theta)\left|y_{i}-x_{i}^{\prime} \beta\right|\right]
$$


Where $\theta \in(0,1)$. Contrary to OLS in Eq. (1) that is based on minimizing the sum of squared residuals; the weighted sums of absolute deviations are minimized in this approach and $\mathrm{k}$ stands for number of explanatory variables. For example, the $75^{\text {th }}$ or $25^{\text {th }}$ quantiles $(\theta=0.75$ or 0.25 respectively) are obtained by weighing the residuals approximately. The conditional quantile of dependent variables $\left(y_{i}\right)$ given the determinants $\left(x_{i}\right)$ is:

$$
Q_{y}\left(\theta \mid x_{i}\right)=x_{i}^{\prime} \beta \theta
$$

Where, unique slope parameters are estimated for each $\theta^{\text {th }}$ quantile (mobile phone penetration). The formulation of Eq. (8) is analogous to $E(y \mid x)=x_{i}^{\prime} \beta$ in the slope of Eq. (1), though parameters are modeled only at the mean of conditional distributions of the variables to be explained. In Eq. (7), the dependent variable $y_{i}$ is a mobile phone penetration indicator, while $x_{i}$ contains a constant term and the determinants.

\section{Empirical results}

\subsection{Determinants of Mobile phone penetrations}

In this section, we present the findings for baseline OLS (Table 5), Fixed-effects (Table 6) and System GMM (Table 7) regressions. For Tables 5-6, the LHS and RHS respectively represent contemporary and non-contemporary specifications. In the latter specifications, the determinants are lagged by one period. The specifications are tailored to avoid potential issues of multicollinearity and overparameterization from the correlation analysis.

In Table 5, the information criteria for the validity of specifications are the Fisher statistics and the Adjusted Coefficient of determination $\left(\mathrm{R}^{2}\right)$. It is apparent that the specifications are all valid at the 1percent significance level. Moreover, corresponding $\mathrm{R}^{2}$ are above 0.500 , which further confirms the explanatory power of the investigated determinants. The following findings can be established. First, from the category of macroeconomic policy 
variables (i) the effects of trade openness, money supply and domestic investment are mixed while (ii) inflation has a positive influence on the dependent variables, with a lower magnitude in the non-contemporary specification. Second, concerning the business/bank related indicators: (i) the effects of net interest margin and lending deposit rate are mixed, (ii) the impacts of bank density and ROA are positive while (iii) the effect of ROE is negative. Third, regarding market-related indicators, (i) the effect of GDP growth is contradictory whereas (ii) the impacts of population growth and urban population are positive. Fourth, on external flows, the impact of foreign aid, foreign investment and remittances are respectively varied, positive and negative. Fifth, for household development, the human development index has a positive effect compared with the negative correlation observed for domestic savings. The impact of household expenditure is insignificantly different from zero. Sixth, with regard to the incidence of knowledge economy, education, regulation quality and internet penetration exert positive influence on mobile phone diffusion whereas the effects of private credit and patent applications are not statistically significant. 
Table 5: Baseline OLS with HAC SE

\begin{tabular}{|c|c|c|c|c|c|c|c|c|c|c|c|c|c|}
\hline & & \multicolumn{6}{|c|}{ Contemporary } & \multicolumn{6}{|c|}{ Non-contemporary } \\
\hline & Constant & $\begin{array}{l}114 * * * \\
(0.000)\end{array}$ & $\begin{array}{l}29.52 * * * \\
(0.001)\end{array}$ & $\begin{array}{l}-239 * * * \\
(0.003)\end{array}$ & $\begin{array}{l}-23.70 \\
(0.136)\end{array}$ & $\begin{array}{l}-18.99 \\
(0.197)\end{array}$ & $\begin{array}{l}-25.24 \\
(0.201)\end{array}$ & $\begin{array}{l}140 * * * \\
(0.000)\end{array}$ & $\begin{array}{l}29.17 * * * \\
(0.002)\end{array}$ & $\begin{array}{l}-190 * * * \\
(0.003)\end{array}$ & $\begin{array}{l}-21.91 \\
(0.178)\end{array}$ & $\begin{array}{l}-21.96 \\
(0.165)\end{array}$ & $\begin{array}{l}-28.21 \\
(0.201)\end{array}$ \\
\hline \multirow{4}{*}{$\begin{array}{l}\text { Policy } \\
\text { Variables }\end{array}$} & Trade & $\begin{array}{l}0.58 \\
(0.165)\end{array}$ & --- & $\begin{array}{l}-1.3 * * * \\
(0.001)\end{array}$ & --- & --- & $\begin{array}{l}-0.047 \\
(0.484)\end{array}$ & $\begin{array}{l}0.89 * \\
(0.096)\end{array}$ & --- & $\begin{array}{l}-0.87 * * \\
(0.012)\end{array}$ & --- & -- & $\begin{array}{l}-0.051 \\
(0.424)\end{array}$ \\
\hline & Money Supply & $\begin{array}{l}-1.35 * * \\
(0.018)\end{array}$ & --- & $\begin{array}{l}0.624 * \\
(0.058)\end{array}$ & --- & --- & --- & $\begin{array}{l}-1.39 * * \\
(0.020)\end{array}$ & --- & $\begin{array}{l}0.53 * * \\
(0.034)\end{array}$ & --- & --- & --- \\
\hline & Inflation & $\begin{array}{l}0.651 \\
(0.537)\end{array}$ & --- & $\begin{array}{l}3.36 * * * \\
(0.006)\end{array}$ & --- & --- & --- & $\begin{array}{l}-0.54 \\
(0.463)\end{array}$ & --- & $\begin{array}{l}1.71 * * * \\
(0.006)\end{array}$ & --- & --- & --- \\
\hline & Domestic Investment & $\begin{array}{l}-1.95 * * \\
(0.033)\end{array}$ & --- & $\begin{array}{l}2.01 * * * \\
(0.001)\end{array}$ & --- & --- & $\begin{array}{l}0.170 \\
(0.718)\end{array}$ & $\begin{array}{l}-2.7 * * * \\
(0.000)\end{array}$ & --- & $\begin{array}{l}1.06 * * * \\
(0.000)\end{array}$ & --- & --- & $\begin{array}{l}0.123 \\
(0.828)\end{array}$ \\
\hline \multirow{5}{*}{$\begin{array}{l}\text { Business/ } \\
\text { Bank } \\
\text { Variables }\end{array}$} & Net Interest Margin & $\begin{array}{l}-4.7 * * * \\
(0.000)\end{array}$ & $\begin{array}{l}-1.47 * \\
(0.085)\end{array}$ & $\begin{array}{l}2.92 * * \\
(0.012)\end{array}$ & --- & --- & $\begin{array}{l}0.043 \\
(0.965)\end{array}$ & $\begin{array}{l}-4.5 * * * \\
(0.000)\end{array}$ & $\begin{array}{l}-1.17 \\
(0.188)\end{array}$ & $\begin{array}{l}2.28 * * \\
(0.045)\end{array}$ & --- & --- & $\begin{array}{l}0.206 \\
(0.850)\end{array}$ \\
\hline & Lending Deposit Rate & $\begin{array}{l}-1.42 \\
(0.170)\end{array}$ & $\begin{array}{l}-0.45 * * \\
(0.015)\end{array}$ & $\begin{array}{l}1.38 * * \\
(0.045)\end{array}$ & --- & -- & $\begin{array}{l}-0.74 * * \\
(0.041)\end{array}$ & $\begin{array}{l}-2.18 * \\
(0.064)\end{array}$ & $\begin{array}{l}-0.44 * * * \\
(0.008)\end{array}$ & $\begin{array}{l}0.188 \\
(0.744)\end{array}$ & --- & --- & $\begin{array}{l}-0.70 * \\
(0.075)\end{array}$ \\
\hline & Bank Density & $\begin{array}{l}6.43 * * \\
(0.016)\end{array}$ & $\begin{array}{l}2.01 * * * \\
(0.000)\end{array}$ & $\begin{array}{l}4.42 * * * \\
(0.005)\end{array}$ & --- & --- & --- & $\begin{array}{l}5.328 * \\
(0.099)\end{array}$ & $\begin{array}{l}2.13 * * * \\
(0.000)\end{array}$ & $\begin{array}{l}2.92 * * * \\
(0.003)\end{array}$ & --- & --- & --- \\
\hline & Return on Assets & $\begin{array}{l}-4.73 \\
(0.244)\end{array}$ & $\begin{array}{l}1.59 \\
(0.332)\end{array}$ & $\begin{array}{l}\text { 6.71*** } \\
(0.008)\end{array}$ & --- & --- & $\begin{array}{l}-0.259 \\
(0.644)\end{array}$ & $\begin{array}{l}-2.88 \\
(0.51)\end{array}$ & $\begin{array}{l}0.908 \\
(0.587)\end{array}$ & $\begin{array}{l}9.68 * * * \\
(0.000)\end{array}$ & --- & --- & $\begin{array}{l}-0.351 \\
(0.526)\end{array}$ \\
\hline & Return on Equity & $\begin{array}{l}0.103 \\
(0.785)\end{array}$ & $\begin{array}{l}-0.18 \\
(0.178)\end{array}$ & $\begin{array}{l}-0.9 * * * \\
(0.000)\end{array}$ & --- & --- & $\begin{array}{l}-0.039 \\
(0.543)\end{array}$ & $\begin{array}{l}-0.09 \\
(0.840)\end{array}$ & $\begin{array}{l}-0.132 \\
(0.326)\end{array}$ & $\begin{array}{l}-1.1 * * * \\
(0.000)\end{array}$ & --- & --- & $\begin{array}{l}-0.027 \\
(0.698)\end{array}$ \\
\hline \multirow{3}{*}{$\begin{array}{l}\text { Market- } \\
\text { related }\end{array}$} & GDP growth & --- & $\begin{array}{l}-0.98 * * * \\
(0.000)\end{array}$ & $\begin{array}{l}2.84 * * * \\
(0.043)\end{array}$ & --- & --- & $\begin{array}{l}-0.36 * \\
(0.081)\end{array}$ & --- & $\begin{array}{l}-0.97 * * * \\
(0.000)\end{array}$ & $\begin{array}{l}1.564 \\
(0.154)\end{array}$ & --- & --- & $\begin{array}{l}-0.239 \\
(0.311)\end{array}$ \\
\hline & Population growth & --- & $\begin{array}{l}-0.25 \\
(0.926)\end{array}$ & $\begin{array}{l}34.8 * * * \\
(0.004)\end{array}$ & --- & --- & --- & --- & $\begin{array}{l}-0.46 \\
(0.868)\end{array}$ & $\begin{array}{l}35.2 * * * \\
(0.002)\end{array}$ & --- & --- & --- \\
\hline & Urban population & --- & $\begin{array}{l}0.502 * * * \\
(0.001)\end{array}$ & $\begin{array}{l}3.82 * * * \\
(0.000)\end{array}$ & --- & --- & $\begin{array}{l}0.286 \\
(0.185)\end{array}$ & --- & $\begin{array}{l}0.56 * * * \\
(0.001)\end{array}$ & $\begin{array}{l}3.64 * * * \\
(0.000)\end{array}$ & --- & --- & $\begin{array}{l}0.295 \\
(0.194)\end{array}$ \\
\hline \multirow{3}{*}{$\begin{array}{l}\text { External } \\
\text { Flows }\end{array}$} & Foreign Investment & --- & --- & --- & $\begin{array}{l}0.362 * \\
(0.077)\end{array}$ & $\begin{array}{l}0.38 * * * \\
(0.001)\end{array}$ & $\begin{array}{l}0.439 \\
(0.390)\end{array}$ & --- & --- & --- & $\begin{array}{l}0.654 \\
(0.179)\end{array}$ & $\begin{array}{l}0.515 \\
(0.118)\end{array}$ & $\begin{array}{l}0.404 \\
(0.538)\end{array}$ \\
\hline & Foreign Aid & --- & --- & --- & $\begin{array}{l}0.015 \\
(0.918)\end{array}$ & $\begin{array}{l}-0.15^{*} \\
(0.070)\end{array}$ & $\begin{array}{l}0.512 * \\
(0.092)\end{array}$ & -- & --- & --- & $\begin{array}{l}0.024 \\
(0.891)\end{array}$ & $\begin{array}{l}-0.155 \\
(0.136)\end{array}$ & $\begin{array}{l}0.569 \\
(0.128)\end{array}$ \\
\hline & Remittances & --- & --- & --- & $\begin{array}{l}-0.193 \\
(0.287)\end{array}$ & $\begin{array}{l}-\mathbf{0 . 4 8} * \\
(0.055)\end{array}$ & $\begin{array}{l}-0.384 \\
(0.327)\end{array}$ & -- & --- & --- & $\begin{array}{l}-0.182 \\
(0.333)\end{array}$ & $\begin{array}{l}-0.481 * \\
(0.051)\end{array}$ & $\begin{array}{l}-0.220 \\
(0.594)\end{array}$ \\
\hline \multirow{3}{*}{$\begin{array}{l}\text { House- } \\
\text { hold } \\
\text { Develo- } \\
\text { pment }\end{array}$} & Human Development & --- & --- & --- & --- & $\begin{array}{l}100.7 * * \\
(0.015)\end{array}$ & --- & --- & --- & --- & --- & $\begin{array}{l}115 * * * * \\
(0.008)\end{array}$ & -- \\
\hline & Household expenditure & --- & --- & --- & $\begin{array}{l}0.217 \\
(0.213)\end{array}$ & -- & --- & --- & --- & --- & $\begin{array}{l}0.199 \\
(0.242)\end{array}$ & --- & --- \\
\hline & Domestic Savings & --- & --- & --- & -- & $\begin{array}{l}-\mathbf{0 . 2 8} * * \\
(0.029)\end{array}$ & $\begin{array}{l}-0.388 \\
(0.153)\end{array}$ & --- & --- & --- & --- & $\begin{array}{l}-0.26 * * \\
(0.032)\end{array}$ & $\begin{array}{l}-0.274 \\
(0.303)\end{array}$ \\
\hline \multirow{5}{*}{$\begin{array}{l}\text { Knowled } \\
\text { ge } \\
\text { Economy }\end{array}$} & Education & --- & --- & --- & $\begin{array}{l}0.77 * * * \\
(0.000)\end{array}$ & --- & $\begin{array}{l}1.10 * * * \\
(0.000)\end{array}$ & --- & --- & --- & $\begin{array}{l}0.82 * * * \\
(0.000)\end{array}$ & --- & $\begin{array}{l}-12.42 \\
(0.238)\end{array}$ \\
\hline & Regulation Quality & --- & --- & --- & $\begin{array}{l}1.67 \\
(0.645)\end{array}$ & $\begin{array}{l}1.590 \\
(0.714)\end{array}$ & $\begin{array}{l}-12.05 \\
(0.195)\end{array}$ & --- & --- & --- & $\begin{array}{l}1.71 \\
(0.669)\end{array}$ & $\begin{array}{l}0.500 \\
(0.912)\end{array}$ & $\begin{array}{l}1.18 * * * \\
(0.000)\end{array}$ \\
\hline & Internet penetration & --- & --- & --- & --- & $\begin{array}{l}1.57 * * * \\
(0.000)\end{array}$ & --- & --- & --- & --- & --- & $\begin{array}{l}1.68 * * * \\
(0.000)\end{array}$ & --- \\
\hline & Private Credit & --- & --- & --- & --- & $\begin{array}{l}0.129 \\
(0.243)\end{array}$ & --- & --- & --- & --- & --- & $\begin{array}{l}0.115 \\
(0.303)\end{array}$ & --- \\
\hline & Patent Applications & --- & --- & --- & $\begin{array}{l}0.0004 \\
(0.500)\end{array}$ & --- & $\begin{array}{l}-0.001 \\
(0.498)\end{array}$ & -- & --- & --- & $\begin{array}{l}0.0008 \\
(0.245)\end{array}$ & -- & $\begin{array}{l}-0.001 \\
(0.522)\end{array}$ \\
\hline Adjusted R² & & 0.785 & 0.606 & 0.929 & 0.502 & 0.574 & 0.585 & 0.78 & 0.623 & 0.963 & 0.531 & 0.562 & 0.581 \\
\hline Fisher & & $10.7 * * *$ & 37.38*** & $27.5 * * *$ & $37.1 * * *$ & 41.0**** & $14.5 * * *$ & $10.1^{* * *}$ & $35.95 * * *$ & $52.2 * * *$ & $38.4^{* * *}$ & $34.5 * * *$ & $13.6 * * *$ \\
\hline Cross Sections & & 6 & 30 & 6 & 37 & 38 & 22 & 6 & 30 & 6 & 36 & 38 & 22 \\
\hline Observations & & 25 & 190 & 25 & 251 & 238 & 145 & 24 & 170 & 24 & 232 & 210 & 138 \\
\hline
\end{tabular}

OLS with HAC SE: Ordinary Least Squares with Heteroscedascticity and Autocorrelation Consistent Standard Errors. ***; **; *: significant levels at $1 \%, 5 \%$ and $10 \%$ respectively. P-values in parentheses.

Table 6 below is based on panel FE controls for unobserved heterogeneity in terms of country-specific effects. The information criteria for the validity of specifications are: Within $\mathrm{R}^{2}$, Least Square Dummy Variable (LSDV) $\mathrm{R}^{2}$ and LSDV Fisher. It is apparent that the specifications are all valid at the 1 percent significance. Moreover, the corresponding Within 
$\mathrm{R}^{2}$ and LSDV $\mathrm{R}^{2}$, are above 0.700 , which further confirms the explanatory power of the investigated determinants.

First, consistent with the OLS findings in Table 5, (i) the impacts of trade openness, money supply and domestic investment are mixed and (ii) the previously positive effect of inflation is now negative. Second, (i) the previously diverse effects of net interest margin and lending-deposit rate are now persistently negative, (ii) the impact of bank deposit is consistently positive while the effect of ROA is now negative and (iii) the formerly negative impact of ROE is now no longer clear-cut. Third, the mixed and positive signs of marketrelated variables are consistent with the baseline OLS findings. Fourth, (i) the previously mixed effects of foreign aid are no longer significant, (ii) the sign of foreign investment changes to negative while (iii) the negative impact of remittances remains unchanged. Fifth, on household development variables, only the human development index remains positively significant because whereas the insignificant incidence of household expenditure is maintained, the negative effect of domestic savings is no longer significant. Sixth, on knowledge economy, (i) education and internet penetration still display positive signs whereas regulation quality now has a negative influence and (ii) the previously insignificant effects of private credit and patent applications are now positive. 
Table 6: Panel Fixed-Effects

\begin{tabular}{|c|c|c|c|c|c|c|c|c|c|c|c|c|c|}
\hline \multirow{6}{*}{$\begin{array}{l}\text { Policy } \\
\text { Variables }\end{array}$} & \multirow[b]{2}{*}{ Constant } & \multicolumn{6}{|c|}{ Contemporary } & \multicolumn{6}{|c|}{ Non-contemporary } \\
\hline & & $\begin{array}{l}-28.65 \\
(0.375)\end{array}$ & $\begin{array}{l}-432 * * * \\
(0.000)\end{array}$ & $\begin{array}{l}-468 * * * \\
(0.000)\end{array}$ & $\begin{array}{l}-85.8 * * * \\
(0.000)\end{array}$ & $\begin{array}{l}-216 * * * \\
(0.000)\end{array}$ & $\begin{array}{l}-96.68 \\
(0.109)\end{array}$ & $\begin{array}{l}\text { 99.94** } \\
(0.012)\end{array}$ & $\begin{array}{l}-464 * * * \\
(0.000)\end{array}$ & $\begin{array}{l}-636 * * * \\
(0.000)\end{array}$ & $\begin{array}{l}-100 * * * \\
(0.000)\end{array}$ & $\begin{array}{l}-232 * * * \\
(0.000)\end{array}$ & $\begin{array}{l}-167 * * \\
(0.013)\end{array}$ \\
\hline & Trade & $\begin{array}{l}1.05 * * * \\
(0.000)\end{array}$ & --- & $\begin{array}{l}0.315 \\
(0.112)\end{array}$ & --- & --- & $\begin{array}{l}-0.22 * * * \\
(0.008)\end{array}$ & $\begin{array}{l}0.30 * * * \\
(0.007)\end{array}$ & --- & $\begin{array}{l}0.104 \\
(0.796)\end{array}$ & --- & -- & $\begin{array}{l}-0.20 * \\
(0.074)\end{array}$ \\
\hline & Money Supply & $\begin{array}{l}-0.11 * \\
(0.071)\end{array}$ & --- & $\begin{array}{l}\text { 0.191* } \\
(0.076)\end{array}$ & --- & --- & --- & $\begin{array}{l}0.16 * * * \\
(0.000)\end{array}$ & --- & $\begin{array}{l}0.298 \\
(0.174)\end{array}$ & --- & --- & -- \\
\hline & Inflation & $\begin{array}{l}-0.27 \\
(0.384)\end{array}$ & --- & $\begin{array}{l}-0.34 \\
(0.558)\end{array}$ & --- & -- & -- & $\begin{array}{l}-0.27 * * \\
(0.024)\end{array}$ & --- & $\begin{array}{l}-0.64 \\
(0.302)\end{array}$ & --- & --- & --- \\
\hline & $\begin{array}{l}\text { Domestic } \\
\text { Investment }\end{array}$ & $\begin{array}{l}-1.01 \\
(0.239)\end{array}$ & --- & $\begin{array}{l}-0.971 \\
(0.354)\end{array}$ & -- & --- & $\begin{array}{l}1.22 * * * \\
(0.000)\end{array}$ & $\begin{array}{l}-2.03 * * \\
(0.015)\end{array}$ & --- & $\begin{array}{l}-2.59 * * * \\
(0.000)\end{array}$ & --- & --- & $\begin{array}{l}1.33 * * * \\
(0.000)\end{array}$ \\
\hline \multirow{7}{*}{$\begin{array}{l}\text { Business/ } \\
\text { Bank } \\
\text { Variables }\end{array}$} & $\begin{array}{l}\text { Net Interest } \\
\text { Margin }\end{array}$ & $\begin{array}{l}1.22 * * * \\
(0.003)\end{array}$ & $\begin{array}{l}-\mathbf{0 . 8 9} * \\
(0.052)\end{array}$ & $\begin{array}{l}-2.65 \\
(0.185)\end{array}$ & -- & --- & $\begin{array}{l}-1.42 * * \\
(0.000)\end{array}$ & $\begin{array}{l}-1.16 \\
(0.318)\end{array}$ & $\begin{array}{l}-0.42 \\
(0.316)\end{array}$ & $\begin{array}{l}-2.02 * * * \\
(0.000)\end{array}$ & --- & --- & $\begin{array}{l}-1.30 * * * \\
(0.002)\end{array}$ \\
\hline & $\begin{array}{l}\text { Lending Deposit } \\
\text { Rate }\end{array}$ & -2.030 & 0.104 & -2.68 & -- & --- & $-1.68 * * *$ & $6.32 * * *$ & 0.196 & $-3.98^{*}$ & --- & --- & $-1.64 * * *$ \\
\hline & & $(0.249)$ & $(0.688)$ & $(0.184)$ & & & $(0.000)$ & $(0.003)$ & $(0.372$ & $(0.077)$ & & & $(0.000)$ \\
\hline & $\begin{array}{l}\text { Interest Rate } \\
\text { Spread }\end{array}$ & -- & -- & -- & --- & --- & --- & -- & --- & -- & --- & --- & --- \\
\hline & Bank Density & $\begin{array}{l}10.6 * * * * \\
(0.000)\end{array}$ & $\begin{array}{l}3.89 * * \\
(0.012)\end{array}$ & $\begin{array}{l}2.96 * * \\
(0.025)\end{array}$ & --- & --- & -- & $\begin{array}{l}6.39 * * * \\
(0.000)\end{array}$ & $\begin{array}{l}3.68 * * * \\
(0.006)\end{array}$ & $\begin{array}{l}-1.49 \\
(0.205)\end{array}$ & -- & -- & --- \\
\hline & Return on Assets & $\begin{array}{l}-1.55 \\
(0.539)\end{array}$ & $\begin{array}{l}0.632 \\
(0.556)\end{array}$ & $\begin{array}{l}-9.6 * * * \\
(0.008)\end{array}$ & --- & -- & $\begin{array}{l}0.328 \\
(0.193)\end{array}$ & $\begin{array}{l}6.50 \\
(0.117)\end{array}$ & $\begin{array}{l}-0.58 \\
(0.453)\end{array}$ & $\begin{array}{l}-3.89 \\
(0.186)\end{array}$ & --- & --- & $\begin{array}{l}0.461 \\
(0.143)\end{array}$ \\
\hline & Return on Equity & $\begin{array}{l}0.150 \\
(0.470)\end{array}$ & $\begin{array}{l}-0.04 \\
(0.585)\end{array}$ & $\begin{array}{l}0.78 * * \\
(0.013)\end{array}$ & --- & --- & $\begin{array}{l}-0.017 \\
(0.670)\end{array}$ & $\begin{array}{l}-0.78 * * \\
(0.049)\end{array}$ & $\begin{array}{l}0.05 \\
(0.445)\end{array}$ & $\begin{array}{l}0.27 \\
(0.172)\end{array}$ & --- & --- & $\begin{array}{l}0.0001 \\
(0.997)\end{array}$ \\
\hline \multirow{3}{*}{$\begin{array}{l}\text { Market- } \\
\text { related }\end{array}$} & GDP growth & -- & $\begin{array}{l}0.21 \\
(0.235)\end{array}$ & $\begin{array}{l}1.435 * \\
(0.064)\end{array}$ & -- & -- & $\begin{array}{l}-0.86 * * * \\
(0.000)\end{array}$ & -- & $\begin{array}{l}0.029 \\
(0.854)\end{array}$ & $\begin{array}{l}0.667 \\
(0.425)\end{array}$ & --- & --- & $\begin{array}{l}-0.78 * * * \\
(0.000)\end{array}$ \\
\hline & Population growth & --- & $\begin{array}{l}1.62 \\
(0.804)\end{array}$ & $\begin{array}{l}-35.18 \\
(0.105)\end{array}$ & --- & --- & --- & --- & $\begin{array}{l}1.43 \\
(0.824)\end{array}$ & $\begin{array}{l}19.49 * * \\
(0.032)\end{array}$ & --- & --- & --- \\
\hline & Urban population & --- & $\begin{array}{l}12.0 * * * \\
(0.000)\end{array}$ & $\begin{array}{l}17.27 * * * \\
(0.000)\end{array}$ & --- & -- & $\begin{array}{l}1.547 \\
(0.391)\end{array}$ & -- & $\begin{array}{l}12.9 * * * \\
(0.000)\end{array}$ & $\begin{array}{l}22.09 * * * \\
(0.000)\end{array}$ & --- & -- & $\begin{array}{l}3.54^{*} \\
(\mathbf{0 . 0 8 5})\end{array}$ \\
\hline \multirow{4}{*}{$\begin{array}{l}\text { External } \\
\text { Flows }\end{array}$} & $\begin{array}{l}\text { Foreign } \\
\text { Investment }\end{array}$ & --- & --- & --- & 0.306 & 0.139 & $-0.496 *$ & --- & --- & --- & 0.377 & 0.104 & $-0.425^{*}$ \\
\hline & & & & & $(0.312)$ & $(0.362)$ & $(\mathbf{0 . 0 6 2})$ & & & & $(0.360)$ & $(0.748)$ & $(\mathbf{0 . 0 9 0 )}$ \\
\hline & Foreign Aid & --- & --- & --- & $\begin{array}{l}0.185 \\
(0.285)\end{array}$ & $\begin{array}{l}-0.051 \\
(0.502)\end{array}$ & $\begin{array}{l}-0.002 \\
(0.989)\end{array}$ & -- & --- & --- & $\begin{array}{l}0.127 \\
(0.588)\end{array}$ & $\begin{array}{l}-0.056 \\
(0.545)\end{array}$ & $\begin{array}{l}-0.029 \\
(0.872)\end{array}$ \\
\hline & Remittances & --- & --- & -- & $\begin{array}{l}-0.187 \\
(0.431)\end{array}$ & $\begin{array}{l}\mathbf{0 . 7 5} * * * \\
(0.000)\end{array}$ & $\begin{array}{l}-0.060 \\
(0.814)\end{array}$ & --- & -- & --- & $\begin{array}{l}-0.16 \\
(0.488)\end{array}$ & $\begin{array}{l}- \\
0.90 * * * \\
(0.005)\end{array}$ & $\begin{array}{l}0.010 \\
(0.972)\end{array}$ \\
\hline \multirow{3}{*}{$\begin{array}{l}\text { House- } \\
\text { hold } \\
\text { Develo- } \\
\text { pment }\end{array}$} & $\begin{array}{l}\text { Human } \\
\text { Development }\end{array}$ & --- & --- & --- & -- & $\begin{array}{l}493 * * * \\
(0.000)\end{array}$ & --- & --- & --- & --- & --- & $\begin{array}{l}540 * * * \\
(0.000)\end{array}$ & --- \\
\hline & $\begin{array}{l}\text { Household } \\
\text { expenditure }\end{array}$ & --- & --- & --- & $\begin{array}{l}0.054 \\
(0.839)\end{array}$ & --- & --- & --- & --- & --- & $\begin{array}{l}0.130 \\
(0.600)\end{array}$ & -- & --- \\
\hline & Domestic Savings & --- & --- & --- & -- & $\begin{array}{l}-0.341 \\
(0.152)\end{array}$ & $\begin{array}{l}-0.286 \\
(0.221)\end{array}$ & --- & --- & --- & --- & $\begin{array}{l}-0.35 \\
(0.109)\end{array}$ & $\begin{array}{l}-0.29 \\
(0.197)\end{array}$ \\
\hline \multirow{5}{*}{$\begin{array}{l}\text { Knowledg } \\
\text { e } \\
\text { Economy }\end{array}$} & Education & --- & --- & -- & $\begin{array}{l}2.51 * * * \\
(0.000)\end{array}$ & -- & $\begin{array}{l}2.06 * * * * \\
(0.000)\end{array}$ & --- & --- & --- & $\begin{array}{l}2.8 * * * * \\
(0.000)\end{array}$ & --- & $\begin{array}{l}2.08 * * * \\
(0.000)\end{array}$ \\
\hline & $\begin{array}{l}\text { Regulation } \\
\text { Quality }\end{array}$ & --- & --- & --- & $\begin{array}{l}-3.627 \\
(0.736)\end{array}$ & $\begin{array}{l}0.922 \\
(0.934)\end{array}$ & $\begin{array}{l}-17.8^{* * * *} \\
(0.003)\end{array}$ & --- & --- & --- & $\begin{array}{l}-9.34 \\
(0.402)\end{array}$ & $\begin{array}{l}-7.51 \\
(0.551)\end{array}$ & $\begin{array}{l}-21.4 * * * \\
(0.004)\end{array}$ \\
\hline & $\begin{array}{l}\text { Internet } \\
\text { penetration }\end{array}$ & --- & --- & --- & -- & $\begin{array}{l}1.34 * * * \\
(\mathbf{0 . 0 0 0 )}\end{array}$ & -- & --- & --- & --- & --- & $\begin{array}{l}1.40 * * \\
(0.012)\end{array}$ & -- \\
\hline & Private Credit & --- & --- & --- & --- & $\begin{array}{l}0.97 * * \\
(0.021)\end{array}$ & --- & --- & -- & --- & --- & $\begin{array}{l}0.871 * \\
(0.060)\end{array}$ & --- \\
\hline & $\begin{array}{l}\text { Patent } \\
\text { Applications }\end{array}$ & --- & --- & --- & $\begin{array}{l}0.01 * * * \\
(0.000)\end{array}$ & --- & $\begin{array}{l}0.009 * * * \\
(0.000)\end{array}$ & --- & --- & --- & $\begin{array}{l}\mathbf{0 . 0 0 9} * * \\
* \\
(\mathbf{0 . 0 0 0})\end{array}$ & -- & $\begin{array}{l}0.007 * * * \\
(0.000)\end{array}$ \\
\hline $\mathrm{LSDV}^{2}$ & & 0.983 & 0.909 & 0.995 & 0.857 & 0.859 & 0.929 & 0.798 & 0.926 & 0.998 & 0.869 & 0.866 & 0.933 \\
\hline Within $\mathrm{R}^{2}$ & & 0.859 & 0.713 & 0.963 & 0.715 & 0.725 & 0.825 & 0.798 & 0.712 & 0.976 & 0.712 & 0.716 & 0.831 \\
\hline LSDV Fisher & & $42.9 * * *$ & $41.4 * * *$ & $96.06 * * *$ & $28.91 * * *$ & $26.0 * * *$ & $39.6^{* * * *}$ & $42.2 * * *$ & $44.9^{* * *}$ & $203 * * *$ & $29.8 * * *$ & $23.6^{* * * *}$ & $39.2 * * *$ \\
\hline Cross Sections & & 6 & 30 & 6 & 37 & 38 & 22 & 6 & 30 & 6 & 36 & 38 & 22 \\
\hline Observations & & 25 & 190 & 25 & 251 & 238 & 145 & 24 & 170 & 24 & 232 & 210 & 138 \\
\hline
\end{tabular}

OLS with HAC SE: Ordinary Least Squares with Heteroscedascticity and Autocorrelation Consistent Standard Errors. ***; **; *: significant levels at $1 \%, 5 \%$ and $10 \%$ respectively. P-values in parentheses. 
The dynamic system GMM results are presented in Table 7 below. Four principal information criteria are employed to assess the validity of the GMM model with forward orthogonal deviations ${ }^{3}$.

Looking at the findings, but for bank density and urban population, (i) the human development index and education are consistently positive in Tables 5-7 across specifications and (ii) the signs of the other variables are conflicting.

Table 7: Dynamic System GMM with Forward Orthogonal Deviations

\begin{tabular}{|c|c|c|c|c|c|c|c|c|}
\hline & \multicolumn{8}{|c|}{ Dependent Variable: Mobile Phone Penetration Rate } \\
\hline & Mobile (-1) & $\begin{array}{l}1.10 * * * \\
(0.000)\end{array}$ & $\begin{array}{l}1.038 * * * \\
(0.000)\end{array}$ & $\begin{array}{l}1.156 * * * \\
(0.000)\end{array}$ & $\begin{array}{l}0.973 * * * \\
(0.000)\end{array}$ & $\begin{array}{l}1.003 * * * \\
(0.000)\end{array}$ & $\begin{array}{l}1.107 * * * \\
(0.000)\end{array}$ & $\begin{array}{l}1.051 * * * \\
(0.000)\end{array}$ \\
\hline & Constant & -1.289 & $-4.313 *$ & 0.070 & -3.216 & $-25.47 * * *$ & -0.885 & 1.399 \\
\hline & & $(0.576)$ & $(0.053)$ & $(0.980)$ & $(0.479)$ & $(0.000)$ & $(0.498)$ & $(0.374)$ \\
\hline & Trade & $\begin{array}{l}\mathbf{0 . 0 4 3}^{* *} \\
(0.011)\end{array}$ & --- & --- & --- & --- & & \\
\hline & Inflation & -0.013 & --- & $-0.015 * *$ & --- & --- & --- & --- \\
\hline Policy & & $(0.548)$ & & $(0.049)$ & & & & \\
\hline Variables & Domestic Investment & $\begin{array}{l}0.079 \\
(0.210)\end{array}$ & --- & $\begin{array}{l}0.054 \\
(0.315)\end{array}$ & --- & --- & --- & --- \\
\hline \multirow{6}{*}{$\begin{array}{l}\text { Business/ } \\
\text { Bank } \\
\text { Variables }\end{array}$} & Net Interest Margin & $\begin{array}{l}-0.34 * * \\
(0.026)\end{array}$ & --- & $\begin{array}{l}-0.265 * * \\
(0.042)\end{array}$ & --- & --- & --- & --- \\
\hline & Lending Deposit Rate & $\begin{array}{l}0.005 \\
(0.925)\end{array}$ & --- & & --- & --- & --- & --- \\
\hline & Interest Rate Spread & --- & --- & $\begin{array}{l}0.042 \\
(0.171)\end{array}$ & --- & --- & --- & --- \\
\hline & Bank Density & --- & $\begin{array}{l}0.155 * \\
(0.084)\end{array}$ & & --- & --- & --- & --- \\
\hline & Return on Assets & --- & $\begin{array}{l}0.293 \\
(0.109)\end{array}$ & $\begin{array}{l}-0.188 \\
(0.242)\end{array}$ & --- & --- & --- & $\begin{array}{l}0.047 \\
(0.515)\end{array}$ \\
\hline & Return on Equity & --- & $\begin{array}{l}-0.018 \\
(0.405)\end{array}$ & & --- & --- & $\begin{array}{l}-0.010 \\
(0.298)\end{array}$ & --- \\
\hline \multirow{3}{*}{$\begin{array}{l}\text { Market- } \\
\text { related }\end{array}$} & GDP growth & --- & $\begin{array}{l}0.113 * * * \\
(0.001)\end{array}$ & --- & --- & --- & --- & --- \\
\hline & Population growth & --- & $\begin{array}{l}0.695 \\
(0.207)\end{array}$ & --- & --- & --- & --- & \\
\hline & Urban population & --- & $\begin{array}{l}0.195 * * * \\
(0.000)\end{array}$ & --- & --- & --- & --- & $\begin{array}{l}0.143 * * * \\
(0.000)\end{array}$ \\
\hline \multirow{3}{*}{$\begin{array}{l}\text { External } \\
\text { Flows }\end{array}$} & Foreign Investment & --- & --- & --- & $\begin{array}{l}0.037 \\
(0.333)\end{array}$ & $\begin{array}{l}0.054 * * * \\
(0.000)\end{array}$ & $\begin{array}{l}0.074 * \\
(0.095)\end{array}$ & $\begin{array}{l}-0.061 \\
(0.242)\end{array}$ \\
\hline & Foreign Aid & --- & --- & --- & $\begin{array}{l}-0.014 \\
(0.490)\end{array}$ & $\begin{array}{l}0.021 * * * \\
(0.005)\end{array}$ & $\begin{array}{l}0.041 * * * \\
(0.006)\end{array}$ & $\begin{array}{l}0.040 * * * \\
(0.003)\end{array}$ \\
\hline & Remittances & -- & --- & --- & $\begin{array}{l}-\mathbf{0 . 0 5 8} * * \\
(\mathbf{0 . 0 1 1})\end{array}$ & --- & $\begin{array}{l}0.082 \\
(0.239)\end{array}$ & $\begin{array}{l}0.104 * * \\
(0.038)\end{array}$ \\
\hline \multirow{2}{*}{$\begin{array}{l}\text { House- } \\
\text { hold } \\
\text { Develo- }\end{array}$} & Human Development & --- & --- & --- & --- & $\begin{array}{l}68.13 * * * \\
(0.000)\end{array}$ & -- & -- \\
\hline & Household expenditure & --- & --- & --- & $\begin{array}{l}0.003 \\
(0.955)\end{array}$ & --- & --- & --- \\
\hline
\end{tabular}

\footnotetext{
3 "First, the null hypothesis of the second-order Arellano and Bond autocorrelation test $(A R(2))$ in difference for the absence of autocorrelation in the residuals should not be rejected. Second the Sargan and Hansen overidentification restrictions (OIR) tests should not be significant because their null hypotheses are the positions that instruments are valid or not correlated with the error terms. In essence, while the Sargan OIR test is not robust but not weakened by instruments, the Hansen OIR is robust but weakened by instruments. In order to restrict identification or limit the proliferation of instruments, we have ensured that instruments are lower than the number of cross-sections in most specifications. Third, the Difference in Hansen Test (DHT) for exogeneity of instruments is also employed to assess the validity of results from the Hansen OIR test. Fourth, a Fischer test for the joint validity of estimated coefficients is also provided" (Asongu \& De Moor, 2016, p.9).
} 


\begin{tabular}{|c|c|c|c|c|c|c|c|c|}
\hline pment & Domestic Savings & --- & --- & --- & --- & $\begin{array}{l}0.002 \\
(0.899)\end{array}$ & $\begin{array}{l}0.056 * \\
(0.097)\end{array}$ & $\begin{array}{l}-0.004 \\
(0.880)\end{array}$ \\
\hline \multirow{5}{*}{$\begin{array}{l}\text { Knowledge } \\
\text { Economy }\end{array}$} & Education & --- & --- & --- & $\begin{array}{l}0.150 * * * \\
(0.000)\end{array}$ & --- & --- & --- \\
\hline & Regulation Quality & --- & --- & --- & --- & $\begin{array}{l}-1.921 * * \\
(0.032)\end{array}$ & $\begin{array}{l}-0.029 \\
(0.984)\end{array}$ & $\begin{array}{l}2.223 \\
(0.104)\end{array}$ \\
\hline & Internet penetration & -- & --- & --- & --- & $\begin{array}{l}-0.237 * * * \\
(0.000)\end{array}$ & -- & -- \\
\hline & Private Credit & --- & --- & --- & --- & $\begin{array}{l}-\mathbf{0 . 0 8 5} * * * \\
(0.000)\end{array}$ & --- & --- \\
\hline & Patent Applications & --- & --- & --- & $\begin{array}{l}-\mathbf{0 . 0 0 0 5} * * * * \\
(\mathbf{0 . 0 0 0 )}\end{array}$ & --- & $\begin{array}{l}0.0005 * * \\
(0.030)\end{array}$ & --- \\
\hline \multicolumn{2}{|l|}{$\mathrm{AR}(1)$} & $(0.003)$ & $(0.001)$ & $(0.004)$ & $(0.073)$ & $(0.026)$ & $(0.000)$ & $(0.001)$ \\
\hline \multicolumn{2}{|l|}{$\mathrm{AR}(2)$} & $(0.490)$ & (0.383) & $(0.455)$ & $(0.604)$ & $(0.677)$ & $(0.473)$ & $(0.482)$ \\
\hline \multicolumn{2}{|l|}{ Sargan OIR } & (0.601) & $(0.008)$ & (0.632) & $(0.038)$ & (0.144) & $(0.005)$ & $(0.062)$ \\
\hline \multicolumn{2}{|l|}{ Hansen OIR } & (0.949) & (0.374) & (0.691) & $(0.790)$ & $(0.652)$ & $(0.386)$ & $(0.480)$ \\
\hline \multicolumn{9}{|c|}{$\begin{array}{l}\text { DHT for Instruments } \\
\text { (a) Instruments in levels }\end{array}$} \\
\hline & $(0.516)$ & (0.112) & $(0.738)$ & (0.299) & $(0.678)$ & (0.169) & $(0.312)$ \\
\hline \multicolumn{2}{|c|}{ Dif(null, $\mathrm{H}=$ exogenous) } & \multicolumn{7}{|c|}{ (b) IV (years, eq (diff)) } \\
\hline \multicolumn{2}{|c|}{$\mathrm{H}$ excluding group } & $(0.680)$ & $(0.209)$ & $(0.928)$ & $(0.554)$ & $(0.395)$ & $(0.078)$ & $(0.370)$ \\
\hline \multicolumn{2}{|c|}{ Dif(null, $\mathrm{H}=$ exogenous) } & $(0.947)$ & $(0.696)$ & $(0.370)$ & $(0.840)$ & $(0.782)$ & $(0.980)$ & $(0.573)$ \\
\hline \multicolumn{2}{|l|}{ Fisher } & $12578 * * *$ & $2882 * * *$ & $36726 * * *$ & $1.05 \mathrm{e}+06 * * *$ & $22335 * * *$ & $6.68 \mathrm{e}+07 * * *$ & $10053 * * *$ \\
\hline \multicolumn{2}{|l|}{ Instruments } & 33 & 34 & 33 & 41 & 41 & 40 & 40 \\
\hline \multicolumn{2}{|l|}{ Countries } & 29 & 41 & 30 & 36 & 44 & 37 & 37 \\
\hline \multicolumn{2}{|l|}{ Observations } & 248 & 285 & 251 & 249 & 261 & 305 & 305 \\
\hline
\end{tabular}

***,**,*: significance levels at 1\%, 5\% and 10\% respectively. DHT: Difference in Hansen Test for Exogeneity of Instruments' Subsets. Dif: Difference. OIR: Over-identifying Restrictions Test. The significance of bold values is twofold. 1) The significance of estimated coefficients, Hausman test and the Fisher statistics. 2) The failure to reject the null hypotheses of: (a) no autocorrelation in the AR(1) \& $\mathrm{AR}(2)$ tests and (b) the validity of the instruments in the Sargan OIR test. P-values in parentheses.

Two main reasons could be advanced for these differences. First, while OLS neither controls for time- nor country-effects, Fixed-effects (system GMM) control for countryspecific effects (both country- and time-effects). Second, the specifications are sensitive to sample periodicity, such that the sign and magnitudes of estimated coefficients are contingent on observations available in the sample consistent with a given specification. One way to tackle these issues is to adopt an estimation technique that consistently employs the same observations across specifications. We adopt a Quantile Regression (QR) approach because, in addition to tackling the underlying estimation problem, it also allows us to assess the determinants throughout the conditional distributions of mobile phone penetration. This enables us to distinguish the determinants in poor-performing countries from those of their better-performing counterparts. 


\subsection{Panel Conditional Determinants}

Table 8 below consists of 6 different specifications that are tailored to mitigate potential multicollinearity issues identified in Table 4. The information criterion for the validity of specifications is the Pseudo $\mathrm{R}^{2}$. It is apparent that the specifications are worthwhile because the explanatory powers are fairly high. Accordingly, in percentage terms, very few coefficients of adjustment are less than 10 percent. It is interesting to note that some QR studies exclusively rely on the significance of estimated coefficients for the validity of specifications(see Okada \& Samreth, 2012).

While, contemporary and non-contemporary results are almost identical, what is quite interesting with respect to previous findings from Tables 5-7 is that the OLS findings significantly change when the dependent variable is assessed throughout its conditional distributions. This justifies our intuition for adopting this estimation technique in order to address the issues arising from preceding regressions. The following findings can be established.

On the first specification (i) the negative effect of trade is apparent only the $0.50^{\text {th }}$ and $0.75^{\text {th }}$ quantiles while that of inflation is visible only in the $0.10^{\text {th }}$ and $0.90^{\text {th }}$ quantiles, (ii) domestic investment has a positive impact in the $0.50^{\text {th }}$ and $0.75^{\text {th }}$ quantiles whereas we find a threshold evidence on the effect of education with a positive magnitude increasing from the $0.10^{\text {th }}$ to the $0.75^{\text {th }}$ quantile.

Second, the following are observable for the second specification. (i) The negative effects of net interest margin and lending-deposit rate in the OLS specification are fundamentally driven by the $0.75^{\text {th }}$ and $0.90^{\text {th }}$ quantiles of the conditional distribution. (ii) The positive effect of bank density is consistent across the distribution in a wave-like trend, while the impact of ROE is negative with an increasing magnitude up to the $0.75^{\text {th }}$ quantile. 
Third, (i) while growth displays a negative effect at the $0.90^{\text {th }}$ quantile, there is evidence of positive threshold impacts from urban population and internet penetration from the $0.25^{\text {th }}$ to $0.90^{\text {th }}$ quantile and $0.10^{\text {th }}$ to $0.75^{\text {th }}$ quantile respectively. (ii) The negative effect of remittances is driven only by the $0.75^{\text {th }}$ quantile while the positive impact of private credit has a Kuznets shape in bottom quantiles $\left(0.10^{\text {th }}\right.$ to $\left.0.50^{\text {th }}\right)$.

Fourth, thresholds are also apparent for: (i) regulation quality and human development with positive increasing magnitudes throughout the distributions; (ii) foreign investment with positive growing magnitudes from the $0.10^{\text {th }}$ to the $0.75^{\text {th }}$ quantiles; (iii) foreign aid with increasing negative magnitude from the $0.10^{\text {th }}$ to the $0.50^{\text {th }}$ quantile and (iv) patent applications with positive decreasing magnitudes throughout the distribution (with the $0.75^{\text {th }}$ quantile insignificant).

Table 8: Panel Conditional determinants of Mobile phone penetration

\begin{tabular}{|c|c|c|c|c|c|c|c|c|c|c|c|c|}
\hline & \multicolumn{6}{|c|}{ Contemporary } & \multicolumn{6}{|c|}{ Non-contemporary } \\
\hline & OLS & Q 0.10 & Q 0.25 & Q 0.50 & Q 0.75 & Q 0.90 & OLS & Q 0.10 & Q 0.25 & Q 0.50 & Q 0.75 & Q 0.90 \\
\hline Constant & $\begin{array}{l}-7.523 * * \\
(\mathbf{0 . 0 3 1})\end{array}$ & $\begin{array}{l}-5.72 * * * \\
(0.000)\end{array}$ & $\begin{array}{l}-4.641 * * \\
(0.013)\end{array}$ & $\begin{array}{l}-7.73 * * * \\
(0.000)\end{array}$ & $\begin{array}{l}-7.154 \\
(0.113)\end{array}$ & $\begin{array}{l}4.114 \\
(0.481)\end{array}$ & $\begin{array}{l}-7.523 * * \\
(0.031)\end{array}$ & $\begin{array}{l}-5.72 * * * \\
(0.000)\end{array}$ & $\begin{array}{l}-4.641 * * \\
(0.013)\end{array}$ & $\begin{array}{l}-7.73 * * * \\
(0.000)\end{array}$ & $\begin{array}{l}-7.154 \\
(0.113)\end{array}$ & $\begin{array}{l}4.114 \\
(0.481)\end{array}$ \\
\hline Trade & $\begin{array}{l}-0.016 \\
(0.719)\end{array}$ & $\begin{array}{l}-0.005 \\
(0.609)\end{array}$ & $\begin{array}{l}-0.003 \\
(0.849)\end{array}$ & $\begin{array}{l}-0.061 * * * * \\
(0.000)\end{array}$ & $\begin{array}{l}-\mathbf{0 . 0 8 5} * * \\
(0.048)\end{array}$ & $\begin{array}{l}0.064 \\
(0.336)\end{array}$ & $\begin{array}{l}-0.016 \\
(0.719)\end{array}$ & $\begin{array}{l}-0.005 \\
(0.609)\end{array}$ & $\begin{array}{l}-0.003 \\
(0.849)\end{array}$ & $\begin{array}{l}-0.061 * * * \\
(0.000)\end{array}$ & $\begin{array}{l}-0.085 * * \\
(0.048)\end{array}$ & $\begin{array}{l}0.064 \\
(0.336)\end{array}$ \\
\hline Inflation & $\begin{array}{l}-0.032 \\
(0.266)\end{array}$ & $\begin{array}{l}-0.04 * * * \\
(0.000)\end{array}$ & $\begin{array}{l}-0.001 \\
(0.921)\end{array}$ & $\begin{array}{l}0.013 \\
(0.442)\end{array}$ & $\begin{array}{l}0.003 \\
(0.916)\end{array}$ & $\begin{array}{l}-0.089 * * \\
(0.025)\end{array}$ & $\begin{array}{l}-0.032 \\
(0.266)\end{array}$ & $\begin{array}{l}-0.04 * * * \\
(0.000)\end{array}$ & $\begin{array}{l}-0.001 \\
(0.921)\end{array}$ & $\begin{array}{l}0.013 \\
(0.442)\end{array}$ & $\begin{array}{l}0.003 \\
(0.916)\end{array}$ & $\begin{array}{l}-0.089 * * \\
(0.025)\end{array}$ \\
\hline Domestic Investment & $\begin{array}{l}0.191 \\
(0.210)\end{array}$ & $\begin{array}{l}0.039 \\
(0.426)\end{array}$ & $\begin{array}{l}0.015 \\
(0.837)\end{array}$ & $\begin{array}{l}0.176 * * \\
(0.014)\end{array}$ & $\begin{array}{l}0.300^{*} \\
(0.089)\end{array}$ & $\begin{array}{l}0.073 \\
(0.780)\end{array}$ & $\begin{array}{l}0.191 \\
(0.210)\end{array}$ & $\begin{array}{l}0.039 \\
(0.426)\end{array}$ & $\begin{array}{l}0.015 \\
(0.837)\end{array}$ & $\begin{array}{l}0.176 * * \\
(0.014)\end{array}$ & $\begin{array}{l}0.300^{*} \\
(0.089)\end{array}$ & $\begin{array}{l}0.073 \\
(0.780)\end{array}$ \\
\hline Education & $\begin{array}{l}0.722 * * * \\
(\mathbf{0 . 0 0 0 )}\end{array}$ & $\begin{array}{l}0.243 * * * \\
(0.000)\end{array}$ & $\begin{array}{l}\mathbf{0 . 3 3} * * * \\
(\mathbf{0 . 0 0 0 )}\end{array}$ & $\begin{array}{l}0.723 * * * \\
(0.000)\end{array}$ & $\begin{array}{l}1.036 * * * \\
(0.000)\end{array}$ & $\begin{array}{l}0.963 * * * \\
(0.000)\end{array}$ & $\begin{array}{l}0.722 * * * \\
(0.000)\end{array}$ & $\begin{array}{l}0.243 * * * \\
(0.000)\end{array}$ & $\begin{array}{l}0.331 * * * \\
(0.000)\end{array}$ & $\begin{array}{l}0.723 * * * \\
(0.000)\end{array}$ & $\begin{array}{l}1.03 * * * \\
(0.000)\end{array}$ & $\begin{array}{l}0.96 * * * \\
(0.000)\end{array}$ \\
\hline Fisher & $59.10 * * *$ & --- & --- & --- & --- & --- & $59.10 * * *$ & --- & --- & --- & -- & -- \\
\hline Adjusted/Pseudo R ${ }^{2}$ & 0.421 & 0.074 & 0.147 & 0.248 & 0.323 & 0.359 & 0.421 & 0.074 & 0.147 & 0.248 & 0.323 & 0.359 \\
\hline Observations & 320 & 320 & 320 & 320 & 320 & 320 & 320 & 320 & 320 & 320 & 320 & 320 \\
\hline & OLS & Q 0.10 & Q 0.25 & Q 0.50 & Q 0.75 & Q 0.90 & OLS & Q 0.10 & Q 0.25 & Q 0.50 & Q 0.75 & Q 0.90 \\
\hline Constant & $\begin{array}{l}\text { 45.56*** } \\
(0.000)\end{array}$ & $\begin{array}{l}4.002 \\
(0.213)\end{array}$ & $\begin{array}{l}12.39 * * * \\
(0.000)\end{array}$ & $\begin{array}{l}\text { 33.28**** } \\
(\mathbf{0 . 0 0 0 )}\end{array}$ & $\begin{array}{l}\text { 78.25*** } \\
(0.000)\end{array}$ & $\begin{array}{l}94.02 * * * \\
(0.000)\end{array}$ & $\begin{array}{l}45.56 * * * \\
(0.000)\end{array}$ & $\begin{array}{l}4.002 \\
(0.213)\end{array}$ & $\begin{array}{l}12.39 * * * \\
(0.000)\end{array}$ & $\begin{array}{l}33.28 * * * \\
(0.000)\end{array}$ & $\begin{array}{l}\text { 78.2 } * * * \\
(0.000)\end{array}$ & $\begin{array}{l}\text { 94.0**** } \\
(0.000)\end{array}$ \\
\hline Net Interest Margin & $\begin{array}{l}-2.157 * \\
(0.054)\end{array}$ & $\begin{array}{l}-0.110 \\
(0.743)\end{array}$ & $\begin{array}{l}-0.448 \\
(0.237)\end{array}$ & $\begin{array}{l}-1.435 \\
(0.133)\end{array}$ & $\begin{array}{l}-3.58 * * * \\
(0.001)\end{array}$ & $\begin{array}{l}-4.118 * * \\
(0.013)\end{array}$ & $\begin{array}{l}-2.157 * \\
(0.054)\end{array}$ & $\begin{array}{l}-0.110 \\
(0.743)\end{array}$ & $\begin{array}{l}-0.448 \\
(0.237)\end{array}$ & $\begin{array}{l}-1.435 \\
(0.133)\end{array}$ & $\begin{array}{l}-3.58 * * * \\
(0.001)\end{array}$ & $\begin{array}{l}-4.11 * * \\
(0.013)\end{array}$ \\
\hline Lending Deposit Rate & $\begin{array}{l}-0.368^{*} \\
(0.067)\end{array}$ & $\begin{array}{l}-0.025 \\
(0.710)\end{array}$ & $\begin{array}{l}-0.033 \\
(0.783)\end{array}$ & $\begin{array}{l}-0.166 \\
(0.559)\end{array}$ & $\begin{array}{l}-0.599 * * \\
(0.044)\end{array}$ & $\begin{array}{l}-0.70 * * * \\
(0.004)\end{array}$ & $\begin{array}{l}-0.368^{*} \\
(0.063)\end{array}$ & $\begin{array}{l}-0.025 \\
(0.710)\end{array}$ & $\begin{array}{l}-0.033 \\
(0.783)\end{array}$ & $\begin{array}{l}-0.166 \\
(0.559)\end{array}$ & $\begin{array}{l}-0.59 * * \\
(0.044)\end{array}$ & $\begin{array}{l}-0.70 * * * \\
(0.004)\end{array}$ \\
\hline Bank Density & $\begin{array}{l}2.212 * * * \\
(0.000)\end{array}$ & $\begin{array}{l}2.29 * * * \\
(0.000)\end{array}$ & $\begin{array}{l}2.22 * * * * \\
(0.000)\end{array}$ & $\begin{array}{l}2.49 * * * \\
(0.000)\end{array}$ & $\begin{array}{l}1.865 * * * \\
(0.000)\end{array}$ & $\begin{array}{l}2.651 * * * * \\
(0.000)\end{array}$ & $\begin{array}{l}2.212 * * * \\
(0.000)\end{array}$ & $\begin{array}{l}2.296 * * * \\
(0.000)\end{array}$ & $\begin{array}{l}2.229 * * * \\
(0.000)\end{array}$ & $\begin{array}{l}2.492 * * * \\
(0.000)\end{array}$ & $\begin{array}{l}1.86 * * * \\
(0.000)\end{array}$ & $\begin{array}{l}2.65 * * * \\
(0.000)\end{array}$ \\
\hline Return on Equity & $\begin{array}{l}-0.105 \\
(0.231)\end{array}$ & $\begin{array}{l}-0.085 * * * \\
(0.000)\end{array}$ & $\begin{array}{l}-\mathbf{0 . 1 2} * * * \\
(0.000)\end{array}$ & $\begin{array}{l}-0.158 \\
(0.143)\end{array}$ & $\begin{array}{l}-0.26 * * * \\
(0.007)\end{array}$ & $\begin{array}{l}-0.247 * * \\
(0.034)\end{array}$ & $\begin{array}{l}-0.105 \\
(0.230)\end{array}$ & $\begin{array}{l}-0.085 * * * \\
(0.000)\end{array}$ & $\begin{array}{l}-0.129 * * * \\
(0.000)\end{array}$ & $\begin{array}{l}-0.158 * * * \\
(0.000)\end{array}$ & $\begin{array}{l}-0.26 * * * \\
(0.007)\end{array}$ & $\begin{array}{l}-0.24 * * \\
(0.040)\end{array}$ \\
\hline Fisher & $52.08 * * *$ & --- & -- & --- & --- & --- & $52.08 * * *$ & --- & --- & --- & -- & -- \\
\hline Adjusted/Pseudo R ${ }^{2}$ & 0.514 & 0.289 & 0.305 & 0.316 & 0.370 & 0.383 & 0.514 & 0.289 & 0.305 & 0.316 & 0.370 & 0.383 \\
\hline Observations & 194 & 194 & 194 & 194 & 194 & 194 & 194 & 194 & 194 & 194 & 194 & 194 \\
\hline & OLS & Q 0.10 & Q 0.25 & Q 0.50 & Q 0.75 & Q 0.90 & OLS & Q 0.10 & Q 0.25 & Q 0.50 & Q 0.75 & Q 0.90 \\
\hline Constant & $\begin{array}{l}-4.893 \\
(0.398)\end{array}$ & $\begin{array}{l}-1.017 \\
(0.256)\end{array}$ & $\begin{array}{l}-0.387 \\
(0.414)\end{array}$ & $\begin{array}{l}-3.131 * \\
(0.071)\end{array}$ & $\begin{array}{l}-3.056 \\
(0.402)\end{array}$ & $\begin{array}{l}6.473 \\
(0.239)\end{array}$ & $\begin{array}{l}-4.893 \\
(0.398)\end{array}$ & $\begin{array}{l}-1.017 \\
(0.256)\end{array}$ & $\begin{array}{l}-0.387 \\
(0.414)\end{array}$ & $\begin{array}{l}-3.131 * \\
(0.071)\end{array}$ & $\begin{array}{l}-3.056 \\
(0.402)\end{array}$ & $\begin{array}{l}6.473 \\
(0.239)\end{array}$ \\
\hline GDP growth & $\begin{array}{l}0.029 \\
(0.841)\end{array}$ & $\begin{array}{l}0.043 \\
(0.365)\end{array}$ & $\begin{array}{l}0.029 \\
(0.225)\end{array}$ & $\begin{array}{l}0.083 \\
(0.227)\end{array}$ & $\begin{array}{l}-0.083 \\
(0.500)\end{array}$ & $\begin{array}{l}-0.439 * * \\
(0.018)\end{array}$ & $\begin{array}{l}0.029 \\
(0.841)\end{array}$ & $\begin{array}{l}0.043 \\
(0.365)\end{array}$ & $\begin{array}{l}0.029 \\
(0.225)\end{array}$ & $\begin{array}{l}0.083 \\
(0.227)\end{array}$ & $\begin{array}{l}-0.083 \\
(0.500)\end{array}$ & $\begin{array}{l}-0.43 * * \\
(0.018)\end{array}$ \\
\hline Population growth & -0.053 & 0.034 & -0.237 & -0.005 & -0.703 & -2.408 & -0.053 & 0.034 & -0.237 & -0.005 & -0.703 & -2.408 \\
\hline
\end{tabular}




\begin{tabular}{|c|c|c|c|c|c|c|c|c|c|c|c|c|}
\hline & $(0.974)$ & $(0.906)$ & $(0.111)$ & $(0.991)$ & $(0.498)$ & $(0.117)$ & $(0.974)$ & $(0.906)$ & $(0.111)$ & $(0.991)$ & $(0.498)$ & $(0.117)$ \\
\hline \multirow[t]{2}{*}{ Urban population } & $0.464 * * *$ & 0.015 & $0.047 * * *$ & $0.199 * * *$ & $0.626 * * *$ & $0.964 * * *$ & $0.464 * * *$ & 0.015 & $0.047 * * *$ & $0.199 * * *$ & $0.62 * * *$ & $0.96 * * *$ \\
\hline & $(0.000)$ & $(0.154)$ & $(0.000)$ & $(0.000)$ & $(0.000)$ & $(0.000)$ & $(0.000)$ & $(0.154)$ & $(0.000)$ & $(0.000)$ & $(0.000)$ & $(0.000)$ \\
\hline \multirow[t]{2}{*}{ Internet penetration } & $2.771 * * *$ & $2.059 * * *$ & $2.626 * * *$ & $3.186 * * *$ & $3.644 * * *$ & $3.474 * * *$ & $2.771 * * *$ & 2.059*** & $2.626 * * *$ & $3.186 * * *$ & $3.64 * * *$ & $3.47 * * *$ \\
\hline & $(0.000)$ & $(0.000)$ & $(0.000)$ & $(0.000)$ & $(0.000)$ & $(0.000)$ & $(0.000)$ & $(0.000)$ & $(0.000)$ & $(0.000)$ & $(0.000)$ & $(0.000)$ \\
\hline Fisher & $171.8 * * *$ & --- & --- & --- & --- & --- & $171.8 * * *$ & --- & --- & --- & --- & --- \\
\hline Adjusted/Pseudo R² & 0.556 & 0.173 & 0.315 & 0.392 & 0.420 & 0.451 & 0.556 & 0.173 & 0.315 & 0.392 & 0.420 & 0.451 \\
\hline \multirow[t]{2}{*}{ Observations } & 545 & 545 & 545 & 545 & 545 & 545 & 545 & 545 & 545 & 545 & 545 & 545 \\
\hline & OLS & Q 0.10 & Q 0.25 & Q 0.50 & Q 0.75 & Q 0.90 & OLS & Q 0.10 & Q 0.25 & Q 0.50 & Q 0.75 & Q 0.90 \\
\hline Constant & $\begin{array}{l}\text { 37.41**** } \\
(\mathbf{0 . 0 0 0 )}\end{array}$ & $\begin{array}{l}2.736 * * * \\
(0.000)\end{array}$ & $\begin{array}{l}9.10 * * * \\
(0.000)\end{array}$ & $\begin{array}{l}\text { 23.78**** } \\
(0.000)\end{array}$ & $\begin{array}{l}54.96 * * * * \\
(0.000)\end{array}$ & $\begin{array}{l}80.42 * * * * \\
(0.000)\end{array}$ & $\begin{array}{l}\text { 37.41**** } \\
(0.000)\end{array}$ & $\begin{array}{l}\text { 2.736*** } \\
(0.000)\end{array}$ & $\begin{array}{l}9.10 * * * \\
(0.000)\end{array}$ & $\begin{array}{l}23.78 * * * \\
(0.000)\end{array}$ & $\begin{array}{l}54.9 * * * \\
(0.000)\end{array}$ & $\begin{array}{l}\text { 80.4*** } \\
(0.000)\end{array}$ \\
\hline \multirow[t]{2}{*}{ Foreign Investment } & $0.971 * * *$ & $0.640 * * *$ & $0.729 * * *$ & $0.987 * * *$ & $1.558 * * *$ & $0.853 * * *$ & $0.971 * * *$ & $0.640 * * *$ & $0.729 * * *$ & $0.987 * * *$ & $1.55 * * *$ & $0.85 * * *$ \\
\hline & $(0.000)$ & $(0.000)$ & $(0.000)$ & $(0.000)$ & $(0.000)$ & $(0.008)$ & $(0.000)$ & $(0.000)$ & $(0.000)$ & $(0.000)$ & $(0.000)$ & $(0.008)$ \\
\hline \multirow[t]{2}{*}{ Foreign Aid } & $-0.391 *$ & $-0.082 * * *$ & $-0.147 * * *$ & $-0.205 *$ & -0.325 & -0.307 & $-0.391 *$ & $-0.082 * * *$ & $-0.14 * * *$ & $-0.205 *$ & -0.325 & -0.307 \\
\hline & $(0.091)$ & $(0.000)$ & $(0.000)$ & $(0.067)$ & $(0.211)$ & $(0.422)$ & $(0.091)$ & $(0.000)$ & $(0.000)$ & $(0.067)$ & $(0.211)$ & $(0.442)$ \\
\hline \multirow[t]{2}{*}{ Remittances } & $-0.238 *$ & -0.028 & -0.018 & -0.163 & -0.541 & -0.437 & $-0.238 *$ & -0.028 & -0.018 & -0.163 & $-0.54 * *$ & -0.437 \\
\hline & $(0.080)$ & $(0.582)$ & $(0.832)$ & $(0.391)$ & (0.048) & $(0.131)$ & $(0.080)$ & $(0.582)$ & $(0.832)$ & $(0.391)$ & $(0.048)$ & $(0.131)$ \\
\hline \multirow[t]{2}{*}{ Regulation Quality } & $17.25 * * *$ & $2.866 * * *$ & $7.194 * * *$ & $13.70 * * *$ & $26.04 * * *$ & $29.13 * * *$ & $17.25 * * *$ & $2.866 * * *$ & $7.194 * * *$ & $13.70 * * *$ & $26.0 * * *$ & $29.1 * * *$ \\
\hline & $(0.000)$ & $(0.000)$ & $(0.000)$ & $(0.000)$ & $(0.000)$ & $(0.000)$ & $(0.000)$ & $(0.000)$ & $(0.000)$ & $(0.000)$ & $(0.000)$ & $(0.000)$ \\
\hline Fisher & $21.38 * * *$ & --- & --- & --- & --- & --- & $21.38 * * *$ & --- & --- & --- & --- & --- \\
\hline Adjusted/Pseudo R² & 0.172 & 0.046 & 0.071 & 0.096 & 0.119 & 0.158 & 0.172 & 0.046 & 0.071 & 0.096 & 0.119 & 0.158 \\
\hline \multirow[t]{2}{*}{ Observations } & 392 & 392 & 392 & 392 & 392 & 392 & 392 & 392 & 392 & 392 & 392 & 392 \\
\hline & OLS & Q 0.10 & Q 0.25 & Q 0.50 & Q 0.75 & Q 0.90 & OLS & Q 0.10 & Q 0.25 & Q 0.50 & Q 0.75 & Q 0.90 \\
\hline \multirow[t]{2}{*}{ Constant } & $-54.0 * * *$ & $-27.9 * * *$ & $-37.6 * * *$ & $-46.5 * * *$ & $-59.7 * * *$ & $-61.8 * * *$ & $-54.0 * * *$ & $-27.9 * * *$ & $-37.6^{* * * *}$ & $-46.5 * * *$ & $-59.7 * * *$ & $-61.8 * * *$ \\
\hline & $(0.000)$ & $(0.000)$ & $(0.000)$ & $(0.000)$ & $(0.000)$ & $(0.000)$ & $(0.000)$ & $(0.000)$ & $(0.000)$ & $(0.000)$ & $(0.000)$ & $(0.000)$ \\
\hline \multirow[t]{2}{*}{ Human Development } & $188.5 * * *$ & 73.60*** & $120.6 * * *$ & $171.4 * * *$ & $226.0 * * *$ & 263.0*** & $188.5 * * *$ & 73.6*** & $120.6 * * *$ & $171.4 * * *$ & $226 * * *$ & $263 * * *$ \\
\hline & $(0.000)$ & $(0.000)$ & $(0.000)$ & $(0.000)$ & $(0.000)$ & $(0.000)$ & $(0.000)$ & $(0.000)$ & $(0.000)$ & $(0.000)$ & $(0.000)$ & $(0.000)$ \\
\hline \multirow[t]{2}{*}{ Domestic Savings } & -0.045 & 0.012 & -0.052 & -0.011 & 0.004 & 0.054 & -0.045 & 0.012 & -0.052 & -0.011 & 0.004 & 0.054 \\
\hline & $(0.530)$ & $(0.824)$ & $(0.310)$ & $(0.847)$ & $(0.955)$ & $(0.547)$ & $(0.530)$ & $(0.824)$ & $(0.310)$ & $(0.847)$ & $(0.955)$ & $(0.574)$ \\
\hline \multirow[t]{2}{*}{ Regulation Quality } & -0.013 & -1.804 & 1.743 & 3.751 & -1.975 & -1.302 & -0.013 & -1.804 & 1.743 & 3.751 & -1.975 & -1.302 \\
\hline & $(0.996)$ & $(0.485)$ & $(0.468)$ & $(0.147)$ & $(0.585)$ & $(0.788)$ & $(0.996)$ & $(0.485)$ & $(0.468)$ & $(0.147)$ & $(0.585)$ & $(0.788)$ \\
\hline \multirow[t]{2}{*}{ Patent Applications } & $0.003 * * *$ & $0.008 * * *$ & $0.006 * * *$ & $\mathbf{0 . 0 0 3} * * *$ & 0.001 & $0.002 * *$ & $0.003 * * *$ & $0.008 * * *$ & $0.006 * * *$ & $\mathbf{0 . 0 0 3} * * *$ & 0.001 & $0.001 * *$ \\
\hline & $(0.000)$ & $(0.000)$ & $(0.000)$ & $(0.001)$ & $(0.306)$ & $(0.017)$ & $(0.000)$ & $(0.000)$ & $(0.000)$ & $(0.001)$ & $(0.306)$ & $(\mathbf{0 . 0 1 7})$ \\
\hline Fisher & $79.00 * * *$ & --- & --- & --- & --- & --- & $79.00 * * *$ & --- & --- & --- & --- & -- \\
\hline Adjusted/Pseudo R² & 0.486 & 0.101 & 0.204 & 0.285 & 0.361 & 0.383 & 0.486 & 0.101 & 0.204 & 0.285 & 0.361 & 0.383 \\
\hline \multirow[t]{2}{*}{ Observations } & 331 & 331 & 331 & 331 & 331 & 331 & 331 & 331 & 331 & 331 & 331 & 331 \\
\hline & OLS & Q 0.10 & Q 0.25 & Q 0.50 & Q 0.75 & Q 0.90 & OLS & Q 0.10 & Q 0.25 & Q 0.50 & Q 0.75 & Q 0.90 \\
\hline \multirow[t]{2}{*}{ Constant } & $-48.3 * * *$ & $-23.4 * * *$ & $-37.8 * * *$ & $-46.7 * * *$ & $-54.9 * * *$ & $-59.7 * * *$ & $-48.3 * * *$ & $-23.4 * * *$ & $-37.8 * * *$ & $-46.7 * * *$ & $-54.9 * * *$ & $-59.7 * * *$ \\
\hline & $(0.001)$ & $(0.001)$ & $(0.000)$ & $(0.005)$ & $(0.001)$ & $(0.001)$ & $(0.000)$ & $(0.001)$ & $(0.000)$ & $(0.005)$ & $(0.001)$ & $(0.001)$ \\
\hline \multirow[t]{2}{*}{ Human Development } & $159.4 * * *$ & $59.43 * * *$ & $100.9 * * *$ & $148.9 * * *$ & $204.9 * * *$ & 243.0*** & $159.4 * * *$ & $59.43 * * *$ & $100.9 * * *$ & $148.9 * * *$ & $204.9 * * *$ & $243 * * *$ \\
\hline & $(0.000)$ & $(0.000)$ & $(0.000)$ & $(0.000)$ & $(0.000)$ & $(0.000)$ & $(0.000)$ & $(0.000)$ & $(0.000)$ & $(0.000)$ & $(0.000)$ & $(0.000)$ \\
\hline \multirow{2}{*}{$\begin{array}{l}\text { Household } \\
\text { expenditure }\end{array}$} & 0.046 & -0.024 & 0.011 & 0.042 & 0.061 & 0.125 & 0.046 & -0.024 & 0.011 & 0.042 & 0.061 & 0.125 \\
\hline & $(0.533)$ & $(0.619)$ & $(0.842)$ & $(0.640)$ & $(0.451)$ & $(0.239)$ & $(0.533)$ & $(0.619)$ & $(0.842)$ & $(0.640)$ & $(0.451)$ & $(0.239)$ \\
\hline Regulation Quality & 0.712 & -0.723 & -0.445 & 0.525 & 2.766 & 5.580 & 0.712 & 0.723 & -0.445 & 0.525 & 2.766 & 5.580 \\
\hline & $(0.844)$ & $(0.754)$ & $(0.887)$ & $(0.900)$ & $(0.490)$ & $(0.293)$ & $(0.844)$ & $(0.754)$ & $(0.887)$ & $(0.900)$ & $(0.490)$ & $(0.296)$ \\
\hline Private Credit & $0.217 * * *$ & $0.296 * * *$ & $0.374 * * *$ & $0.290 * * *$ & 0.101 & 0.051 & $0.217 * * *$ & -0.723 & $0.374 * * *$ & $0.290 * * *$ & 0.101 & 0.051 \\
\hline & $(0.000)$ & $(0.000)$ & $(0.000)$ & $(0.001)$ & $(0.291)$ & $(0.721)$ & $(0.000)$ & $(0.754)$ & $(0.000)$ & $(0.001)$ & $(0.291)$ & $(0.721)$ \\
\hline Fisher & $69.71 * * *$ & -- & -- & -- & --- & --- & $69.71 * * *$ & -- & -- & -- & --- & --- \\
\hline Adjusted/Pseudo R² & 0.486 & 0.107 & 0.229 & 0.303 & 0.362 & 0.369 & 0.486 & 0.107 & 0.229 & 0.303 & 0.362 & 0.369 \\
\hline Observations & 291 & 291 & 291 & 291 & 291 & 291 & 291 & 291 & 291 & 291 & 291 & 291 \\
\hline
\end{tabular}

Notes. Dependent variable is Mobile Phone Penetration. *,**,***, denote significance levels of $10 \%, 5 \%$ and $1 \%$ respectively. Lower quantiles (e.g., Q 0.1) signify nations where the Mobile Phone Penetration is least. P-values in parentheses.

\subsection{Policy syndromes based on fundamental characteristics}

According to Fosu (2013), policy syndromes are situations that have been detrimental to economic prosperity. These include, inter alia: 'state controls', 'state breakdown', 'suboptimal inter temporal resource allocation' and 'administered redistribution'. The author uses 'syndrome free' to qualify a situation where such features are absent or substantially 
missing. The policy syndromes are documented to have been the fundamental cause of postindependence poor economic performance in SSA countries. In this context, we are consistent with Asongu (2015f) who has used fundamental characteristics of African development in the analysis of knowledge economy gaps between Africa and South Korea. In the comparative context, high deviations from knowledge economy (KE) benchmarks are 'policy syndromes' (PS) whereas low dispersions display a 'syndrome-free' (SF) tendency. In this study, PS are fundamental characteristics with higher deviations from benchmarks or their best-performing counterparts whereas SF represents corresponding fundamental characteristics with the lower deviations.

As shown in Table 9 below, Panel A presents the averages of the fundamental characteristics while Panel B shows corresponding PS and SF features. The transition from the LHS to the RHS denotes decreasing dispersions from the benchmark, hence indicating the relevance of decreasing need for policy intervention.

Table 9: Policy syndromes based on fundamental characteristics

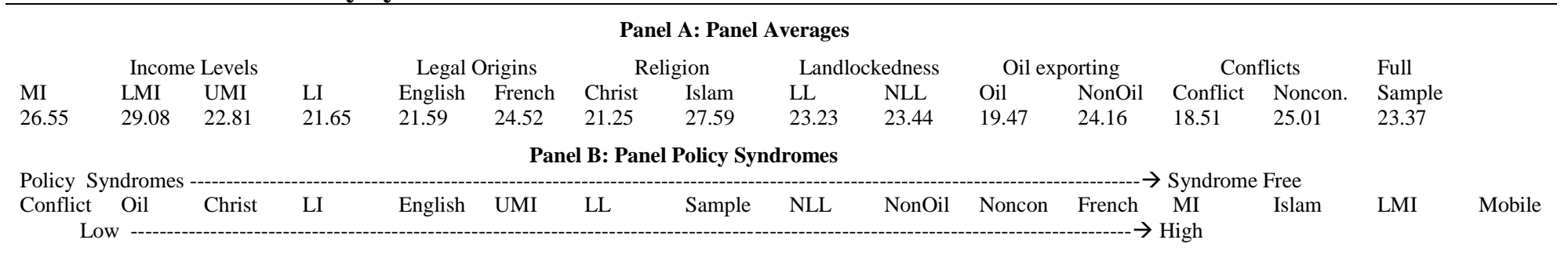

MI: Middle Income. UMI: Upper Middle Income. LMI: Lower Middle Income. LI: Low Income. English: English Common law. French: French Civil law. Christ: Christian. LL: Landlocked. NLL: Not Landlocked. NonOil: Non Oil Exporting. Oil: Oil Exporting. Conflict: Conflict-Affected. Non-Conflict Affected.

\subsection{Further discussion of results and policy implications}

From the established findings, results from Quantile Regressions are more relevant to policy than those from OLS, Fixed Effects and GMM, essentially because they are based on conditional distributions of mobile phone penetration. In essence, whereas estimation by OLS, Fixed Effects and GMM are at the mean value of mobile phone penetration, those by the QR 
technique show countries with low, intermediate and high levels of mobile phone penetration. Furthermore, policy implications based on mean values of mobile phone penetration are unlikely to succeed unless they are contingent on existing levels of mobile phone penetration and tailored differently across countries with intermediate, low and high levels of mobile phone penetration.

To the best of our knowledge, only Doshi and Narwold (2014) in the underlying literature on mobile phone determinants have employed one of the 25 determinants used in this study. The population growth variable is neither significant in the aforementioned study nor in the conditional determinant assessments of the present paper. Thus, in what follows, we discuss the results in the light of intuition and policy implications. Hence, the resulting insights are expositional.

\subsubsection{Non threshold effects}

The non-threshold effects can be summarised as follows: (i) the negative effects of trade and inflation on mobile phone penetration are restricted to the $0.50^{\text {th }}$ and $0.75^{\text {th }}$ and $0.10^{\text {th }}$ and $0.90^{\text {th }}$ quantiles respectively; (ii) the positive impact of domestic investment is apparent only in the $0.50^{\text {th }}$ and $0.75^{\text {th }}$ quantiles; (iii) the negative impacts of net interest margin and lending-deposit rate are driven by the $0.75^{\text {th }}$ and $0.90^{\text {th }}$ quantiles; (iv) bank density is consistently positive across the distribution in a wavelike manner; (v) the negative effect of growth is only apparent in the $0.90^{\text {th }}$ quantile; (vi) the negative effect of remittances is exclusively in the $0.75^{\text {th }}$ quantile and (vii) the positive effect of private credit has a Kuznets shape in the bottom quantiles $\left(0.10^{\text {th }}\right.$ to $\left.0.50^{\text {th }}\right)$.

The following implications are noteworthy for the non-threshold effects. First, the restricted negative effects of trade and inflation imply that (i) neither countries with low initial levels of mobile penetration nor those with the highest should be concerned about the effect of trade openness and (ii) increasing consumer price inflation is an issue only in countries at the 
extremities of the distributions. Second, the limited effect of domestic investment implies that countries with low initial levels in the dependent variable need to tailor investment policies towards increasing the use of mobile phones. Third, the fact that the negative impacts of net interest margin and lending-deposit rate are driven by top quantiles implies that countries with low rates of mobile phones need not worry about this negative effect.

Fourth, we have observed that bank density is consistently positive across the distribution in a wavelike pattern. This may indicate that banks are used as complementary commodities in the accomplishment of certain mobile phone services such as mobile-banking related activities. According to Jonathan and Camilo (2008) and Asongu (2013a, p. 8), mobile phones can be used to fulfil three main services that are directly linked to a bank account. They are to (a) store value or currency in a bank account that is accessible by a handset and in cases where users are already in possession of bank accounts, it becomes a concern of linking the mobile service to the existing bank account. (b) convert money into and out of the account and (c) transfer cash between accounts.

Fifth, the negative effect of economic growth has been established in the highest quantile. Two policy implications are noteworthy. On the one hand, economic prosperity does not necessarily drive mobile phone penetration. On the other, in countries with very high initial levels of mobile phone penetration, economic growth could decrease the usage of mobile phones. While the former scenario could be explained by disequalizing distribution of national wealth, the latter may be the result of people diverting to substitutes of mobile penetration, which has the potential of negatively affecting mobile usage. For the first case, since mobile phone penetration has been established to be pro-poor, the documented unequal wealth distribution in SSA during the sampled periodicity could explain the insignificant effect (Blas, 2014). In the second case, the abundance of mobiles may urge users to recourse to second-hand alternatives, even with burgeoning economic prosperity. 
Sixth, the positive effect of remittances in a top quantile may imply that the use of mobile phones to receive money does not engender to need for more mobile phones. This is essentially because many mobile phones may not be needed per customer for the remittances purposes. Moreover, such transactions are not of high frequency, like other daily transactions.

Seventh, we have observed that private credit has positive effects in the bottom quantile or in countries where existing penetration of mobiles is low. A logical implication is that the availability of credit facilities is associated with activities that engender the need for mobile phones when their usage is low, especially for economic related transactions.

\subsubsection{Threshold effects}

The threshold effects are discussed in three main strands: positive increasing magnitude; decreasing positive magnitude and increasing negative magnitude. It is important to note that, evidence of the first strand responds to the crucial question of why some countries are more advanced than others in mobile phone penetration.

First, there is evidence of positive increasing magnitude or thresholds in: (i) regulation quality and human development throughout the distributions; (ii) foreign investment $\left(0.10^{\text {th }}\right.$ to the $0.75^{\text {th }}$ quantile); (iii) education (between the $0.10^{\text {th }}$ and $0.75^{\text {th }}$ quantiles); (iv) urban population density $\left(0.25^{\text {th }}\right.$ to the $0.90^{\text {th }}$ quantile) and (v) internet penetration (between the $0.10^{\text {th }}$ and $0.75^{\text {th }}$ quantiles).

This implies that best-performing SSA countries are more advanced in mobile penetration rate because of increasing: regulation, human development, foreign investment, education, urban population density and internet penetration. Hence, the benefits of these factors in stimulating mobile usage increases with initial levels of mobile phone usage. These benefits are relevant in decreasing order from the 'policy syndrome' to 'syndrome free' fundamental characteristics presented in Table 9, notably: Conflict, Oil-exporting, Christian, 
Low-income, English common law, Upper-middle-income, Landlocked, Not landlocked, Nonoil-exporting, Non conflict, French civil law, Middle Income, Islam and Lower-middleincome countries.

Second, with the slight exception of the $0.75^{\text {th }}$ quantile, threshold evidence of decreasing positive magnitude is apparent in patent applications throughout the mobile phone distributions. As a policy implication, sampled countries need to work towards mitigating the potentially decreasing benefits of mobile phone penetration from patent applications.

Third, increasingly negative effects are also established for the (i) impact of foreign aid between the $0.10^{\text {th }}$ and $0.50^{\text {th }}$ quantiles and (ii) effect of ROE up to the $0.75^{\text {th }}$ quantile. As a policy implication, foreign aid would need to be tailored more towards improving the benefits of foreign aid in mobile usage.

\section{Conclusion}

Despite the evolving literature on the development benefits of mobile phones, we still know very little about factors that influence their adoption. This study has contributed to existing literature by elucidating why some sub-Saharan African countries are more advanced in mobile phone penetration. Using twenty five policy variables, we have investigated determinants of mobile phone penetration in 49 Sub-Saharan African countries with data for the period 2000-2012. The empirical evidence is based on OLS, Fixed effects, System GMM with forward orthogonal deviations and Quantile regressions techniques. The determinants are classified in six policy categories, notably: macroeconomic, business/bank, market-related, knowledge economy, external flows and human development. The results are presented in terms of threshold and non-threshold effects.

With regard to threshold effect, first there is evidence of positive increasing magnitude in (i) regulation quality and human development throughout the distributions; (ii) foreign 
investment $\left(0.10^{\text {th }}\right.$ to the $0.75^{\text {th }}$ quantile); (iii) education (between the $0.10^{\text {th }}$ and $0.75^{\text {th }}$ quantiles); (iv) urban population density $\left(0.25^{\text {th }}\right.$ to the $0.90^{\text {th }}$ quantile) and (v) internet penetration (between the $0.10^{\text {th }}$ and $0.75^{\text {th }}$ quantiles). This aspect of threshold effect addresses the policy concern of why some countries are more advanced in mobile phone penetration. Hence, there are increasing positive benefits in regulation quality, human development, foreign investment, education, urban population density and internet penetration. Second, with the slight exception of the $0.75^{\text {th }}$ quantile, threshold evidence of decreasing positive magnitude is apparent in patent applications throughout mobile phone distributions. Hence, there is evidence of decreasing positive effects from patent applications. Third, increasingly negative effects are also established for the: (i) impact of foreign aid between the $0.10^{\text {th }}$ and $0.50^{\text {th }}$ quantiles and (ii) effect of ROE up to the $0.75^{\text {th }}$ quantile. As an implication, foreign aid would need to be tailored more towards improving its benefits in mobile usage.

In terms of non-threshold effects: (i) the negative impact of trade and inflation on mobile phone penetration are restricted to the $0.50^{\text {th }}$ and $0.75^{\text {th }}$ and $0.10^{\text {th }}$ and $0.90^{\text {th }}$ quantile respectively; (ii) the positive impact of domestic investment is apparent only in the $0.50^{\text {th }}$ and $0.75^{\text {th }}$ quantiles; (iii) the negative impacts of net interest margin and lending-deposit rate are driven by the $0.75^{\text {th }}$ and $0.90^{\text {th }}$ quantiles; (iv) bank density is consistently positive across the distribution in a wavelike pattern; (v) the negative effect of growth is only apparent in the $0.90^{\text {th }}$ quantile; (vi) the negative effect of remittances is exclusively in the $0.75^{\text {th }}$ quantile and (vii) the positive effect of private credit has a Kuznets shape in the bottom quantiles $\left(0.10^{\text {th }}\right.$ to $\left.0.50^{\text {th }}\right)$.

Policy implications are discussed with specific emphasis on the worst- and bestperforming countries in mobile phone penetration. We also provide policy syndromes based on fundamental characteristics to enhance more targeted implications for least-performing nations. Given the recently documented asymmetry between mobile phone penetration and 
mobile banking activities by the World Bank (Mosheni-Cheraghlou, 2013), investigating thresholds of mobile banking is an interesting future research direction. 


\section{References}

Abu S. T., \& Tsuji, M., (2010). "The Determinants of the Global Mobile Telephone Deployment: An Empirical Analysis”, Informatica Economică, 14(3), pp. 21-32.

Aker, J. C., \& Fafchamps, M., (2010). "How Does Mobile Phone Coverage Affect Farm-Gate Prices? Evidence from West Africa", Department of Economics and the Fletcher School, Tufts University.

Ajzen, I., (1991). "The theory of planned behaviour". Organizational Behavior and Human Decision Processes, 50(2), pp. 179-211.

Ajzen, I., \& Fishbein, M. (1980). Understanding attitudes and predicting social behavior. Englewood Cliffs, NJ: Prentice-Hall.

Akpan, U. S., Isihak, S. R., \& Asongu, S. A., (2014). "Determinants of Foreign Direct Investment in Fast-Growing Economies: A Study of BRICS and MINT", African Governance and Development Institute Working Paper No. 14/002, Yaoundé.

Al Surikhi, H. F., (2012). "Knowledge and Financial Management in Households: An Examination of Married Women's Perspectives in Chadbourn, North Carolina", Capstone Collection, Paper No. 2489, SIT Graduate Institute, Brattleboro.

Arellano, M., \& Bover, O., (1995). "Another Look at the Instrumental Variable Estimation of Error Component Model”. Journal of Econometrics, 68(1), pp. 29-52.

Asongu, S. A., (2013). "How has mobile phone penetration stimulated financial development in Africa", Journal of African Business, 14(1), pp. 7-18.

Asongu, S. A., (2015a). "The impact of mobile phone penetration on African inequality", International Journal of Social Economics, 42(8), pp.706 - 716.

Asongu, S. A., (2015b). "Reinventing foreign aid for inclusive and sustainable development:

Kuznets, Piketty and the great policy reversal", Journal of Economic Surveys:

DOI /10.1111/joes.12109.

Asongu, S. A., (2015c). "Conditional Determinants of Mobile Phones Penetration and Mobile Banking in Sub-Saharan Africa", Journal of the Knowledge Economy. http://link.springer.com/article/10.1007\%2Fs13132-015-0322-z

Asongu, S. A., (2015d). "On Taxation, Political Accountability and Foreign Aid: Empirics to a Celebrated Literature", South African Journal of Economics, 83(2), pp. 180-198.

Asongu, S. A., (2015e). "Knowledge Economy Gaps, Policy Syndromes and Catch-Up Strategies: Fresh South Korean Lessons to Africa", Journal of the Knowledge Economy http://link.springer.com/article/10.1007\%2Fs13132-015-0321-0

Asongu, S. A., (2014a). "Financial development dynamic thresholds of financial globalization: evidence from Africa", Journal of Economic Studies, 41(2), pp. 166-195. 
Asongu, S. A., (2014b). "The impact of health worker migration on development dynamics: evidence of wealth-effects from Africa", The European Journal of Health Economics, 15(2), pp. 187-201.

Asongu, S. A., \& De Moor, L., (2015). "Recent advances in finance for inclusive development: a survey", African Governance and Development Institute Working Paper No. 15/005, Yaoundé.

Asongu, S. A., \& De Moor, L., (2016). "Financial globalisation dynamic thresholds for financial development: evidence from Africa", The European Journal of Development Research, DOI:10.1057/ejdr.2016.10.

Asongu, S. A., \& Kodila-Tedika, O., (2015). "Conditional determinants of FDI in fast emerging economies: an instrumental quantile regression approach", African Governance and Development Institute Working Paper No. 15/003, Yaoundé.

Asongu, S. A., \& Nwachukwu, J. C., (2015). "Drivers of FDI in Fast Growing Developing Countries: Evidence from Bundling and Unbundling Governance", African Governance and Development Institute Working Paper No. 15/001, Yaoundé.

Asongu, S. A., \& Nwachukwu, J. C., (2016a). "The role of governance in mobile phones for inclusive human development in Sub-Saharan Africa”, Technovation, 55-56(SeptemberOctober), pp. 1-13.

Asongu, S. A., \& Nwachukwu, J. C., (2016b). "Foreign Aid and Inclusive Development: Updated Evidence from Africa, 2005-2012", Social Science Quarterly, DOI: $10.1111 /$ ssqu. 12275 .

Asongu, S. A, \& Nwachukwu, J. C., (2016c). "The Mobile Phone in the Diffusion of Knowledge for Institutional Quality in Sub Saharan Africa", World Development, 86 (October), pp. 133-147.

Asongu, S. A, \& Nwachukwu, J. C., (2016d). "Foreign aid and governance in Africa", International Review of Applied Economics, 30(1), pp. 69-88.

Bagozzi, R., (1982). "A field investigation of causal relations among cognitions, affect, intentions, and behaviour”, Journal of Marketing Research, 19 (4), pp. 562-584.

Baltagi, B. H., (2008). "Forecasting with panel data", Journal of Forecasting, 27(2), pp. 153173.

Bauer, S., De Niet, J., Timman, R., \& Kordy, H., (2010). "Enhancement of care through selfmonitoring and tailored feedback via text messaging and their use in the treatment of childhood overweight", Patient Education and Counseling, 79 (2010), pp. 315-319.

Beck, T., Demirgüç-Kunt, A., \& Levine, R., (2003), "Law and finance: why does legal origin matter?”, Journal of Comparative Economics, 31(4), pp. 653-675. 
Billger, S. M., \& Goel, R. K., (2009). "Do existing corruption levels matter in controlling corruption? Cross-country quantile regression estimates", Journal of Development Economics, 90(2), pp. 299-305.

Blas, J., (2014). "Inequality mar Africa's rise", Financial Times (October 5th). http://www.ft.com/intl/cms/s/0/9e74aa50-1e4d-11eab5200144feabdc0.html\#axzz3GWsY4I91 (Accessed: 18/10/2014).

Chan, A., \& Jia, T., (2011). "The Role of Mobile Banking in Facilitating Rural Finance: Reducing Inequality in Financial Services between Urban and Rural Areas", Accenture Banking Services, http://www.accenture.com/SiteCollectionDocuments/PDF/PoV-MobileBanking-051611-EN.pdf (Accessed: 17/03/2015).

Da Costa, T. M. Salomão, P. L., Martha, A. S., Pisa, I. T., \& Sigulem, D., (2010). "The impact of short message service text messages sent as appointment reminders to patients' cell phones at outpatient clinics in São Paulo, Brazil", International Journal of Medical Informatics, 79 (2010), pp. 65-70.

Davis, F., (1989). "Perceived usefulness, perceived ease of use, and user acceptance of information technology", MIS Quarterly, 13(3), pp. 319-340.

Dewan, S., \& Ramaprasad, J., (2014). "Social media, traditional media and music sales", MIS Quarterly, 38(1), pp. 101-128.

Doshi, K. P., \& Narwold, A., (2014). "Determinants of Mobile Phone Penetration Rates in Asia and Africa: A Panel Data Analysis", Proceedings of 9th International Business and Social Science Research Conference6 - 8 January, 2014, Novotel World Trade Centre, Dubai, UAE.

E-agriculture (2012). "Using ICT to enable Agricultural Innovation Systems for Smallholders", e-source book, ICT In Agriculture, Connecting Small Holders to Knowledge, Networks and Institutions, (Forum 4, September 2012). http://www.fao.org/docrep/018/ar130e/ar130e.pdf (Accessed: 18/03/2015).

Fishbein, M., \& Ajzen, I. (1975). Belief, attitude, intention, and behavior: An introduction to theory and research. Reading, MA: Addison-Wesley.

Fosu, A., (2013). "Growth of African Economies: Productivity, Policy Syndromes and the Importance of Institutions", Journal of African Economies, 22(4), pp. 523-551.

Hoffman, J. A., Cunningham, J. R., Suleh, A. J., Sundsmo, A., Dekker, D., Vago, F., \& Munly, K., (2010). "Mobile Direct Observation Treatment for Tuberculosis Patients A Technical Feasibility Pilot Using Mobile Phones in Nairobi, Kenya", American Journal of Preventive Medicine, 39(1), pp. 78-80.

Jonathan, D., \& Camilo, T. (2008). "Mobile banking and economic development: Linking adoption, impact and use". Asian Journal of Communication, 18(4), pp. 318-322. 
Kirui, O. K., Okello, J. J., Nyikal, R. A., \& Njiraini, G. W., (2013). "Impact of Mobile PhoneBased Money Transfer Services in Agriculture: Evidence from Kenya", Quaterly Journal of International Agriculture, 52(2), pp. 141-162.

Kliner, M., Knight, A., Mamvura, C., Wright, J., \& Walley, J., (2013). "Using no-cost mobile phone reminders to improve attendance for HIV test results: a pilot study in rural Swaziland", Infectious Diseases of poverty, 2(12), pp. 1-7.

Koenker, R., \& Hallock, F. K., (2001). "Quantile regression”, Journal of Economic Perspectives, 15(4), pp.143-156.

Love, I., \& Zicchino, L., (2006). "Financial Development and Dynamic Investment Behaviour: Evidence from Panel VAR" .The Quarterly Review of Economics and Finance, 46(2), pp. 190-210.

Madden, G., Coble-Neal, G., \& Dalzell, B., (2004). “A dynamic model of mobile telephony subscription incorporating a network effect", Information Economics and Policy, 28(2), pp. 133-144.

Madden, G., \& Coble-Neal, G., (2004). "Economic determinants of global mobile telephony growth", Information Economics and Policy, 16(4), pp. 519-534.

Maurer, B. (2008, May). Retail electronic payments systems for value transfers in the developing world. Department of Anthropology, University of California.

Micheal, H., (2013). "Mobile penetration in Africa is now at $80 \%$ and growing fast", Phone Area, http://www.phonearena.com/news/Mobile-penetration-in-Africa-is-now-at-80-andgrowing-fast_id50014 (Accessed: 19/03/2015).

Mishra, V., \& Bisht, S. S., (2013). "Mobile banking in a developing economy: A customercentric model for policy formulation", Telecommunications Policy, 37(6-7), pp. 503-514.

Mlachila, M., Tapsoba, R. \& Tapsoba, S. J. A., (2014): “A Quality of Growth Index for Developing Countries: A Proposal”. IMF Working Paper No. 14/172, Washington.

Mosheni-Cheraghlou, A., (2013). "Mobile Banking: Who is in the Driver's Seat?", Working for a World Free of Poverty, The World Bank,

http://blogs.worldbank.org/allaboutfinance/mobile-banking-who-driver-s-seat (Accessed: 19/03/2015).

Mpogole, H., Usanga, H., \& Tedre, M., (2008). "Mobile phones and poverty alleviation: a survey study in rural Tanzania", Proceedings of M4D 2008, Karlstad University, Sweden, pp. $62-72$.

Muto, M., \& Yamano, T., (2009). "The Impact of Mobile Phone Coverage Expansion on Market Participation: Panel Data Evidence from Uganda", World Development, 37(12), pp. 1887-1896.

Nguena, C. L., Tchana, T. F., \& Zeufack, A., (2015). "Housing Finance and Inclusive Growth: Benchmarking, Determinants and Effects', AAYE Policy Research Working Paper Series, No. 15/027, Yaoundé. 
Ojo, A., Janowski, T., \& Awotwi, J., (2012). "Enabling development through governance and mobile technology”, Government Information Quarterly, 30 (2013), pp. S32-S45

Ondiege, P., (2013). "Fostering financial inclusion with mobile banking", African Development Bank.

http://www.proparco.fr/webdav/site/proparco/shared/PORTAILS/Secteur_prive_developpeme nt/PDF/SPD16/SPD16_Peter_Ondiege_UK.pdf (Accessed: 03/02/2015).

Ondiege, P., (2010). "Mobile Banking in Africa: Taking the Bank to the People", Africa Economic Brief, 1(8), pp. 1-16.

Okada, K., \& Samreth, S. (2012). "The effect of foreign aid on corruption: A quantile regression approach”, Economic Letters, 115(2), pp. 240-243.

Penard, T., Poussing, N., Yebe, G. Z., \& Ella, P. N., (2012). "Comparing the Determinants of Internet and Cell Phone Use in Africa: Evidence from Gabon", Communications \& Strategies, 86, 2nd Quarter 2012, pp. 65-83.

Perez, F., Gonzalez, C. J., \& Aaronson, X., (2011). "Village banking development model: FINCA Costa Rica”, Journal of Business Research, 64 (3), pp. 316-324.

Qiang, C. Z., Kuek, S. C., Dymond, A., \& Esselaar, S., (2011). "Mobile Applications for Agricultural and Rural Development", ICT Sector Unit, World Bank http://siteresources.worldbank.org/INFORMATIONANDCOMMUNICATIONANDTECHN OLOGIES/Resources/MobileApplications_for_ARD.pdf (Accessed: 17/03/2015).

Roodman, D., (2009a). "A Note on the Theme of Too Many Instruments", Oxford Bulletin of Economics and Statistics, 71(1), pp. 135-158.

Roodman, D., (2009b). "How to do xtabond2: An introduction to difference and system GMM in Stata", Stata Journal, 9(1), pp. 86-136.

Singh, A. B., (2012). "Mobile banking based money order for India Post: Feasible model and assessing demand potential", Procedia - Social and Behavioral Sciences, 37(2012), pp. 466481.

Ssozi, J., \& Asongu, S. A., (2015). "The Effects of Remittances on Output per Worker in SubSaharan Africa: A Production Function Approach", South African Journal of Economics, DOI: $10.1111 /$ saje.12100.

Tseng, F-M \& Lo, H-Y., (2011). "Antecedents of consumers' intentions to upgrade their mobile phones", Telecommunications Policy, 35(1), pp. 74-86.

UNCTAD. (2002). World Investment Report: Transnational Corporations and Export Competitiveness. New York: United Nations.

Wang, Y-S., Wu, M-C., \& Wang, H-Y., (2009). "Investigating the determinants and age and gender differences in the acceptance of mobile learning", British Journal of Educational Technology, 40(1), pp. 92-118. 
Warren, M., (2007). "The digital vicious cycle: links between social disadvantage and digital exclusion in rural areas". Telecommunications Policy, 31(6-7), pp. 374-388.

West, D. M., (2013). "Improving Health Care through Mobile Medical Devices and Sensors", Centre for Technology and Innovation at Brookings, http://www.brookings.edu/ /media/research/files/papers/2013/10/22\%20mobile\%20medical \%20devices\%20west/west_mobile\%20medical\%20devices_v06 (Accessed: 19/03/2015).

Yousafzai, S. Y., Foxall, G. R., \& Pallister, J. G., (2010). "Explaining Internet Banking Behavior: Theory of Reasoned Action, Theory of Planned Behavior, or Technology Acceptance Model?", Journal of Applied Social Psychology, 2010, 40(5), pp. 1172-1202. 